IFN Working Paper No. 956, 2013

\title{
Taxation of Goods and Services in Sweden (1862-2013)
}

Mikael Stenkula 


\title{
Taxation of Goods and Services in Sweden (1862- 2013) ${ }^{*}$
}

\author{
Mikael Stenkula
}

September, 2015

\begin{abstract}
This paper presents annual Swedish time-series data regarding consumption taxes, i.e., the indirect taxation of goods and services, for the 1862-2013 period. As a share of total state tax revenue, consumption tax revenue was high at the beginning of the period, although as a share of GDP, it was rather low. At the beginning of the period examined, customs duties and specific consumption taxes on alcohol and sugar were the most important sources of revenue. The importance of consumption taxes decreased during World War I. After World War I, consumption taxes began to regain their importance, and taxation of vehicles and tobacco contributed significantly to tax revenue. After another dip during World War II, the tax revenue from consumption taxes increased again following the end of the war, and as a share of GDP, it increased sharply. However, the importance of specific consumption taxes and customs duties, in particular, has fallen dramatically since that time. The mix of specific consumption taxes also shifted with an emphasis on energy and environmental taxes. A permanent general consumption tax was introduced in 1960, and its importance has increased sharply since its introduction, accounting for more than 40 percent of central government revenue toward the end of the period examined.
\end{abstract}

JEL-codes: H20, N43, N44

Keywords: Consumption taxes, Taxation of goods and services, Excise duties, Customs duties, VAT

\footnotetext{
* This is the working paper version of a chapter with the same title published in Swedish Taxation: Developments since 1862 (ch. 4, pp. 179-221), edited by Magnus Henrekson and Mikael Stenkula, New York: Palgrave Macmillan. The author gratefully acknowledges financial support from the Jan Wallander and Tom Hedelius Research Foundation. I am also grateful to Joakim Jansson and Max Brimberg for research assistance and help with collecting data.
} 


\section{Introduction}

The tax systems of most developed countries are highly complex, consisting of a mixture of income taxes (personal and corporate), payroll taxes, property taxes and consumption taxes (taxes on goods and services). The division between these taxes differs across countries, and these divisions have changed substantially over time. Consumption taxes (including customs duties) have historically been an important source of tax revenue. After a decline that lasted until the turn of the millennium, they are once again growing in importance. Consumption taxes, unlike income taxes, do not reduce incentives to save (see, e.g., Slemrod and Bakija 2008).

The purpose of this paper is to analyze consumption taxes in Sweden between 1862 and 2013. The paper offers a detailed description of the various components of consumption taxes - including general and specific consumption taxes in addition to customs duties — and how they have evolved over time. This paper is the first attempt to calculate an annual series of the evolution of consumption taxes for a timespan that is this long.

This paper is organized as follows. In section 2, the data and methodology are discussed. Section 3 presents the general evolution of consumption taxes. Section 4 provides an in-depth discussion covering customs duties, general consumption taxes and specific consumption taxes. Section 5 concludes.

\section{Data and methodology}

Data are taken from several sources. The main source concerning tax revenues is Statistics Sweden (SCB), complemented by information from the Swedish National Financial Management Authority (Ekonomistyrningsverket, ESV) and the OECD. ${ }^{1}$ Tax revenues will be divided between customs duties, general consumption taxes (i.e., consumption taxes not directed at particular goods or services, such as a general sales tax or VAT) and specific consumption taxes (sometimes called excise duties, i.e., consumption taxes on a particular (type of) commodity or service, such as a tax on liquor or fuel). GDP data are taken from Statistics Sweden (SCB) and Edvinsson, Jacobson and Waldenström (2014).

This paper will focus on central state (national) taxation. Consumption taxation at the local (municipality) level was limited during the period examined (and can also differ substantially across municipalities). According to SCB $(1914,177)$, at the beginning of the

\footnotetext{
${ }^{1}$ Statistics Sweden (1914-2010), Ekonomistyrningsverket (2010-2014), OECD stat extracts, http://stats.oecd.org/Index.aspx?

DataSetCode=REV.
} 
period examined there were no consumption taxes at the local level. According to Gårestad (1987, 234), citing a tax committee from 1900, municipalities did not have the legal right to indirectly tax people through consumption taxes. ${ }^{2}$ Nevertheless, the sales tax on liquor from this time period can be understood as a form of semi-local tax. Formally, it was a state tax collected by the state, but it was distributed to the municipalities based on how much liquor was sold in the municipalities. This tax is included in the analysis.

Consumption tax revenue will be shown as a percentage of state and total (i.e., state and local combined) tax revenue and will also be shown as a percentage of GDP. ${ }^{3}$ GDP is rather straightforward to use, but there have been some methodological changes in how to measure tax revenues. ${ }^{4}$ Many of these changes generate temporary and small changes that will not affect the overall pattern. There are, however, some changes that should be mentioned.

One major problem concerns the distinction between reporting gross and net revenues. Some revenues are (or have been) reported as a net figure, correcting for different types of costs or deductions. During the 1990s, an increasing number of figures were reported as gross figures, which mainly affects the evolution of total tax revenue and, to a lesser extent, the tax revenue from different consumption taxes. This reporting change mostly affects general consumption taxes (such as VAT). From 2006, ESV reports VAT as a gross figure without any correction for the VAT paid by authorities and organizations within the governmental (state and local) sector. Prior to 2006, VAT was reported as a net figure, that is, the VAT paid by governmental organizations was reduced from the reported total revenue that VAT generated. $^{5}$

There were several other changes during the 1990s that make a comparison over time less straightforward. One concern relates to accounting principles. Before 2006, tax revenues were based on actual taxes paid each year, i.e., cash-flow. From 2006 onwards, an accrued

\footnotetext{
${ }^{2}$ Although municipalities were not legally entitled to tax people indirectly, they were not forbidden to tax dogs. Hence, there was a specific local dog tax paid by dog owners during the nineteenth century. This indirect tax was, however, of negligible importance. After World War I, local authorities nevertheless introduced luxury consumption taxes, which were later transformed into a state tax. Local authorities also had previously introduced a minor excise duty on forestry (skogsaccis) in 1909. When vehicle transportation grew into a key component of local economies, the County Administrative Board (Länsstyrelsen) was further allowed to introduce local road user charges. This tax was more of a fee than a tax.

${ }^{3}$ Total (or state) revenue can be used instead, but this figure will include temporary and sometimes extraordinarily large revenues, such as sales of state-owned companies, which will result in spikes in the time series. Nonetheless, we included revenue associated with the social security system in the aggregate figure.

${ }^{4}$ One reason for these changes is that the responsibility for maintaining the statistics concerning public finances shifted from Statskontoret, Riksräkenskapsverket and Riksrevisionsverket (and published by Statistics Sweden) to a new body, ESV (Ekonomistyrningsverket), in 1998.

${ }^{5}$ The VAT paid by state authorities was about 20 billion crowns in 2006. The state compensates the organizations for these VAT payments.
} 
revenue system for taxes collected was implemented. ${ }^{6}$ This procedure is normal in the business sector but was not used by the government until 2006. Nevertheless, its usage does not affect consumption taxes very much. Membership in the EU also affected state revenues and its costs, but this change is a real event that should affect the outcome. In regard to specific consumption taxes, there are some reclassification problems that are mainly related to the fuel tax. ${ }^{7}$

Other notable changes concern the treatment of social security revenues and costs, which does not affect consumption taxes per se but does affect consumption tax as a share of total state tax revenue, impairing comparability over time. Hence, the consumption tax share of state tax revenue must be interpreted with caution for the last 20 years of the period examined. This problem does not arise when we use total tax revenue in the denominator, and the different tax components as a share of GDP are also less affected.

\section{General development}

Figure 1 depicts the evolution of consumption tax revenue as a percentage of state tax revenue and as a percentage of total tax revenue over the entire period. Figure 2 depicts the evolution as a share of GDP.

As a share of state tax revenue, consumption taxes have been high. During the late 1800s, this share was as high as $75-85$ percent. At the beginning of the $1900 \mathrm{~s}$, the share began to decline. During World War I, it declined sharply to as low as 12 percent. There were several reasons for this precipitous decline. Customs duties decreased because of restrictions on international trade. Income from taxes on sugar and alcohol, which had been the most important specific consumption taxes (see section 4.2), declined due to rationing. Many consumption taxes were unit taxes (i.e., a constant nominal amount per unit consumed). Due to extremely high inflation during World War I (which was almost 50 percent annually in 1918), tax revenue declined rapidly in real terms. Temporary income taxes were introduced to cover government expenses, including increased military outlays.

\footnotetext{
${ }^{6}$ If taxes paid to the tax authority in January of year $t$ refer to an economic event (income, sales) from December of year $t-1$, the tax revenues are treated as revenue for the year $t-1$, i.e., the year when the economic activity generating the tax revenue was performed. See, e.g., Skatteverket (2012) for a further discussion of methodological changes.

${ }^{7}$ The statistics do not allow the separation of the vehicle tax from the fuel tax before 1947. After 1995, the fuel tax is reclassified and cannot be separated from other energy taxes. This reclassification will not distort the measure of state tax revenue or total tax revenue from specific consumption taxes, but it will make the analysis of the disaggregated categories in Section 4.2 more difficult (see Figure 6).
} 
Many of the temporary income tax increases were made permanent after World War I, and the consumption tax share of state tax revenue increased but did not return to its pre-war level. Just after World War I, it was approximately 40 percent. In the 1920s and 1930s, many new consumption taxes were introduced, and this share grew further. In the mid-1930s, the share approached its pre-war levels. During World War II, the share fell again (to nearly 50 percent), but the fall was far less precipitous than during World War I. A temporary general sales tax was also introduced during this time to compensate for the decline in tax revenue and to strengthen the budget. After World War II, the tax share hovered around 50 percent, after a brief dip to 40 percent in the early 1950 s. $^{8}$ Consumption tax revenue as a percentage of total tax revenue follows the same pattern but at a lower level.

As a share of GDP, the evolution of consumption tax revenue looks very different. Although consumption tax as a share of state and total tax revenue was high during the 1800s, tax revenue as a share of GDP was rather small, oscillating in the three to four percent range until the outbreak of World War I. Revenue declined during World War I but began to increase rapidly after the war; by the mid-1920s, the ratio exceeded the pre-war level. This revenue growth occurred despite the fact that consumption tax revenue as a share of total tax revenue never returned to its pre-war levels. Ignoring the time just after World War II, the consumption tax revenue continued to increase, and its share of GDP oscillated approximately 12 percent during the last three decades examined.

At the beginning of the period, consumption taxes were thus the most important source of revenue for the central government, although total tax revenue as a share of GDP was rather small. By the end of the period, consumption tax revenue was slightly less important in relative terms (though still important, as it constituted 50 percent of state tax revenue), but the consumption tax revenue was now four times larger when measured as a share of GDP. Despite the pronounced increase of consumption tax revenue as a share of GDP since World War II, its share of state tax revenue did not increase to the same extent. One reason for this modest increase is the importance of employer-paid social security contributions and payroll taxes that were introduced toward the end of the 1950s and that increased sharply during the 1960s and 1970s (Du Rietz, Johansson and Stenkula 2015).

\footnotetext{
${ }^{8}$ Of course, the share depends on the evolution of other state taxes as well. During the crisis in the early 1990s, social security contributions paid by employees, for instance, were (re)introduced to bolster the state budget. In 2007, an earned income tax credit was introduced and was extended four times during the 2008-2013 period.
} 
Figure 1. Consumption tax revenue as a percentage of state tax revenue and total tax revenue, 1862-2013.

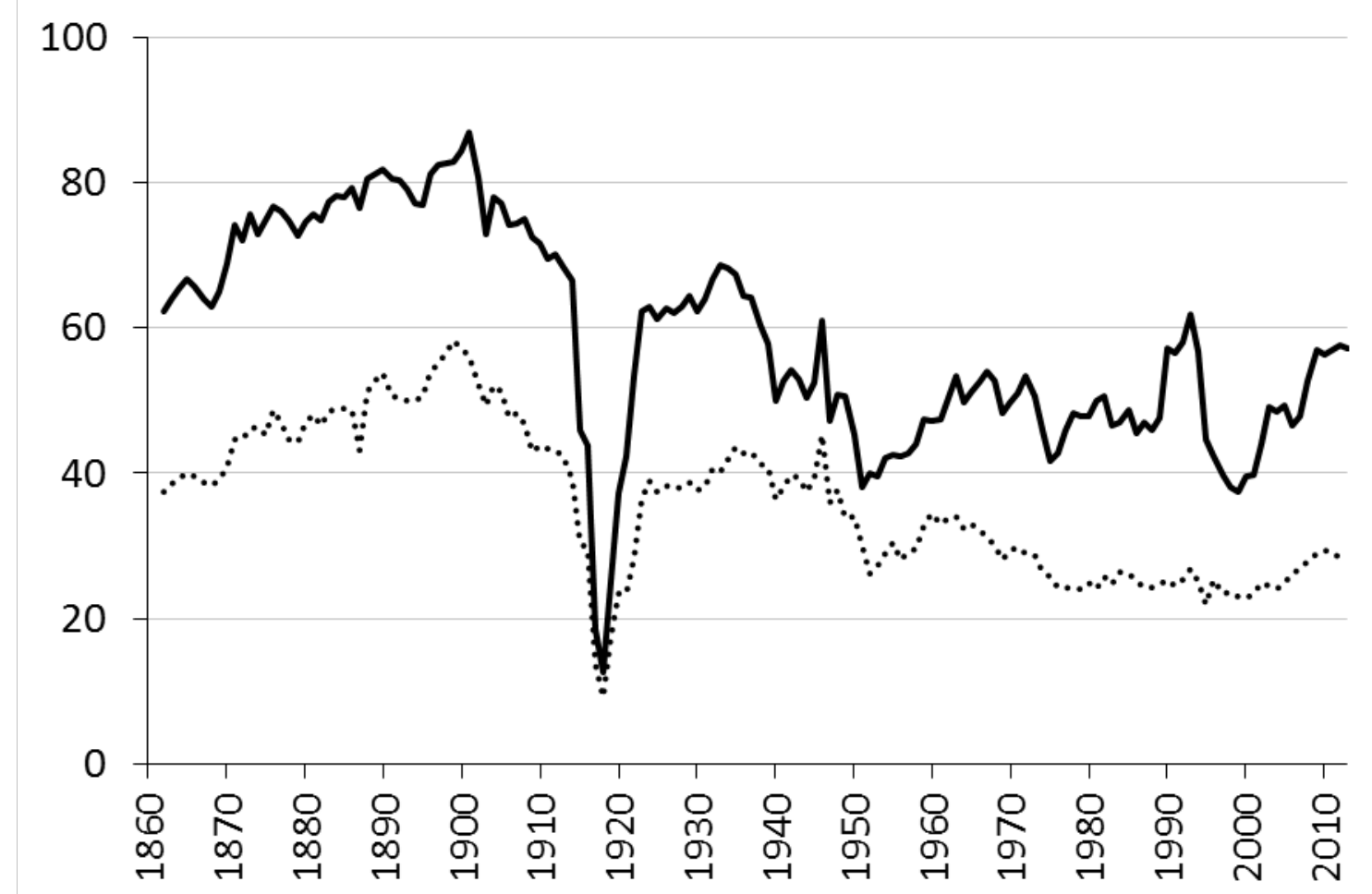

Source: SCB (1914-2011), Ekonomistyrningsverket (2010-2014), Edvinsson, Jacobson and Waldenström (2014), Gårestad (1987) Rodriguez (1980), OECD stat extracts.

http://stats.oecd.org/Index.aspx?DataSetCode=REV.

Figure 2. Consumption tax revenue as a percentage of GDP, 1862-2013.

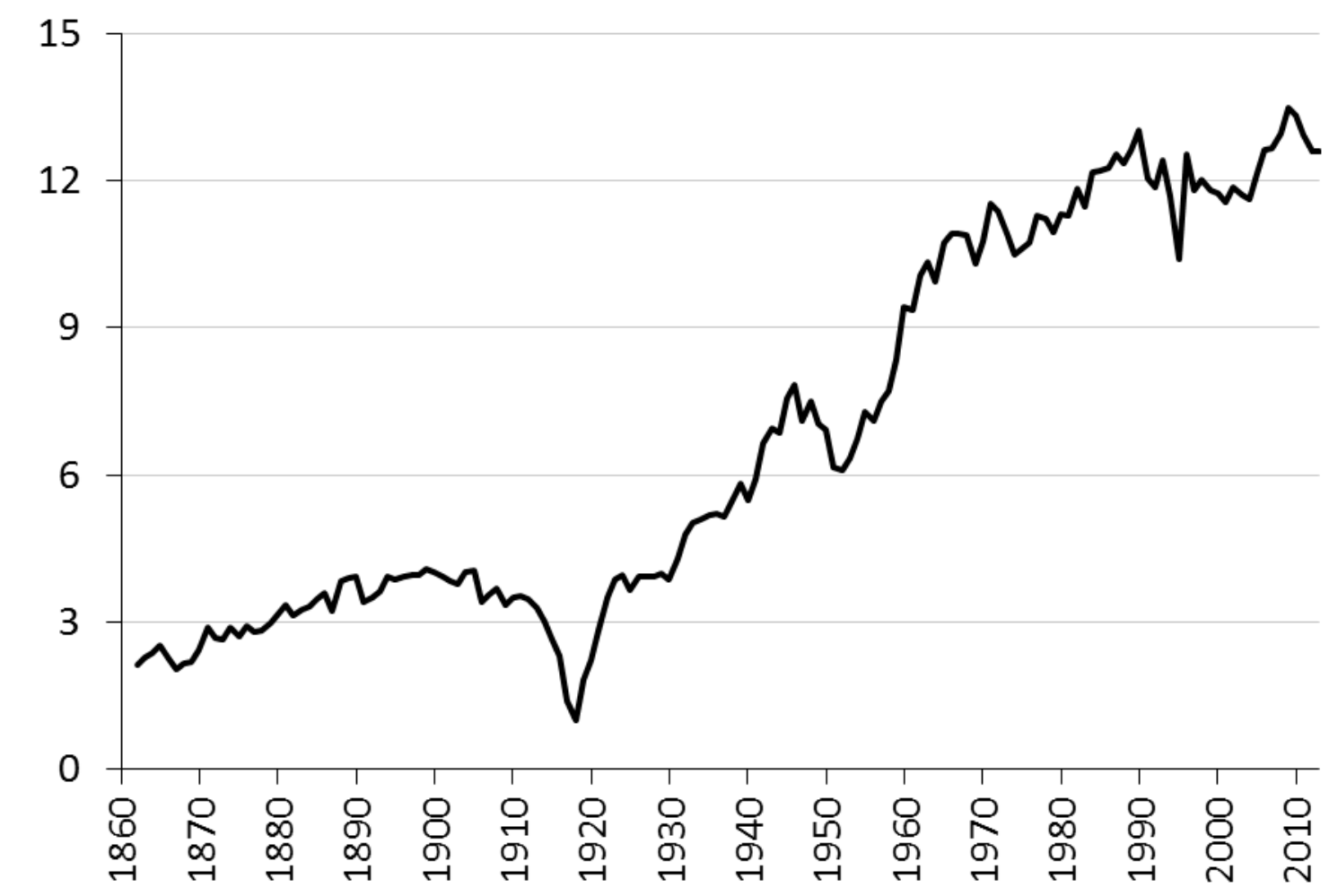

Source: SCB (1914-2011), Ekonomistyrningsverket (2010-2014). 


\section{The composition of consumption taxes}

Figures 3 and 4 show the different types of consumption taxes (customs duties, general consumption taxes and specific consumption taxes) as a share of state and total tax revenues. Each of these types of consumption tax is discussed in more detail below.

Figure 3. Composition of consumption tax revenue as a percentage of state tax revenue, 1862-2013.

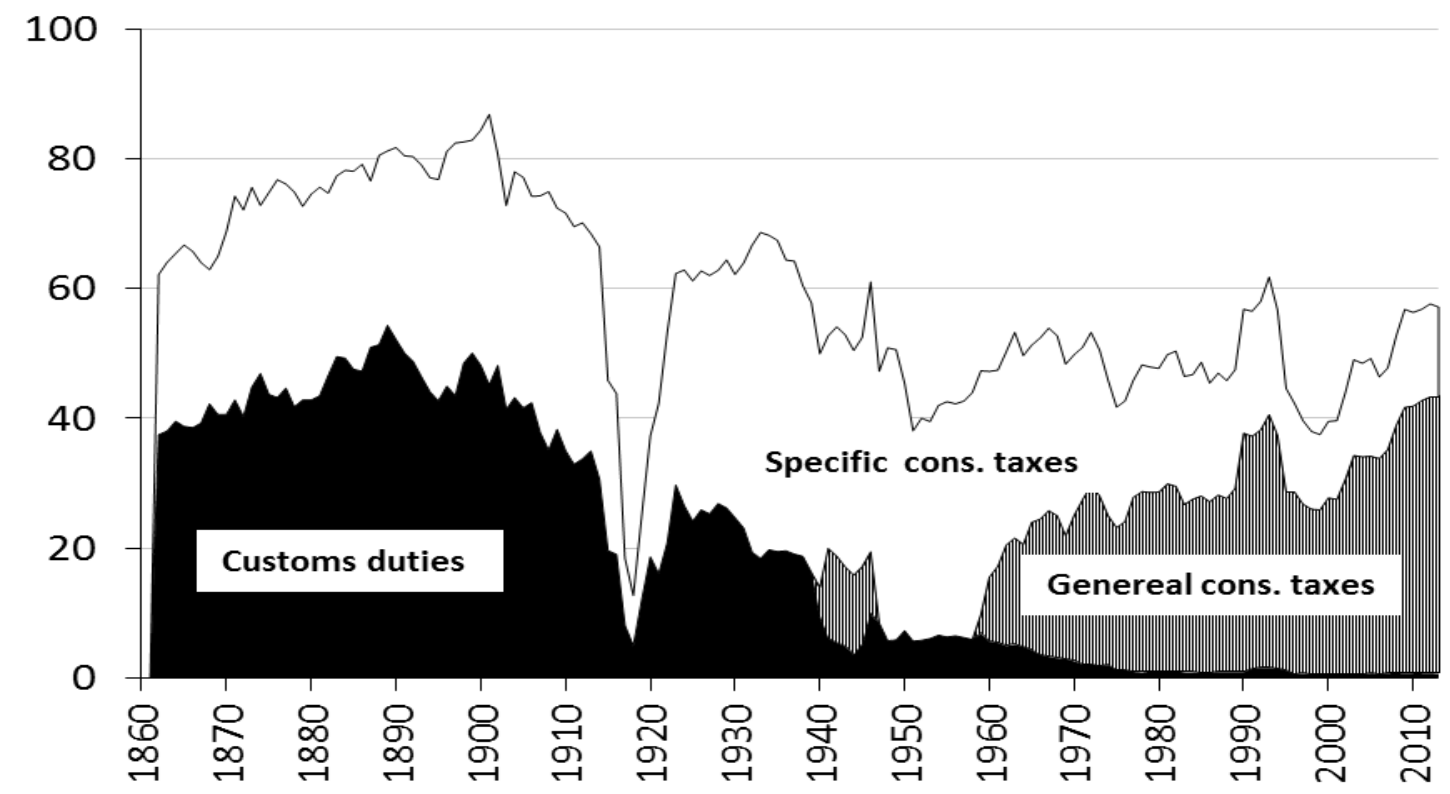

Source: See Figure 1.

Figure 4. Composition of consumption tax revenue as a percentage of total tax revenue, 18622013.

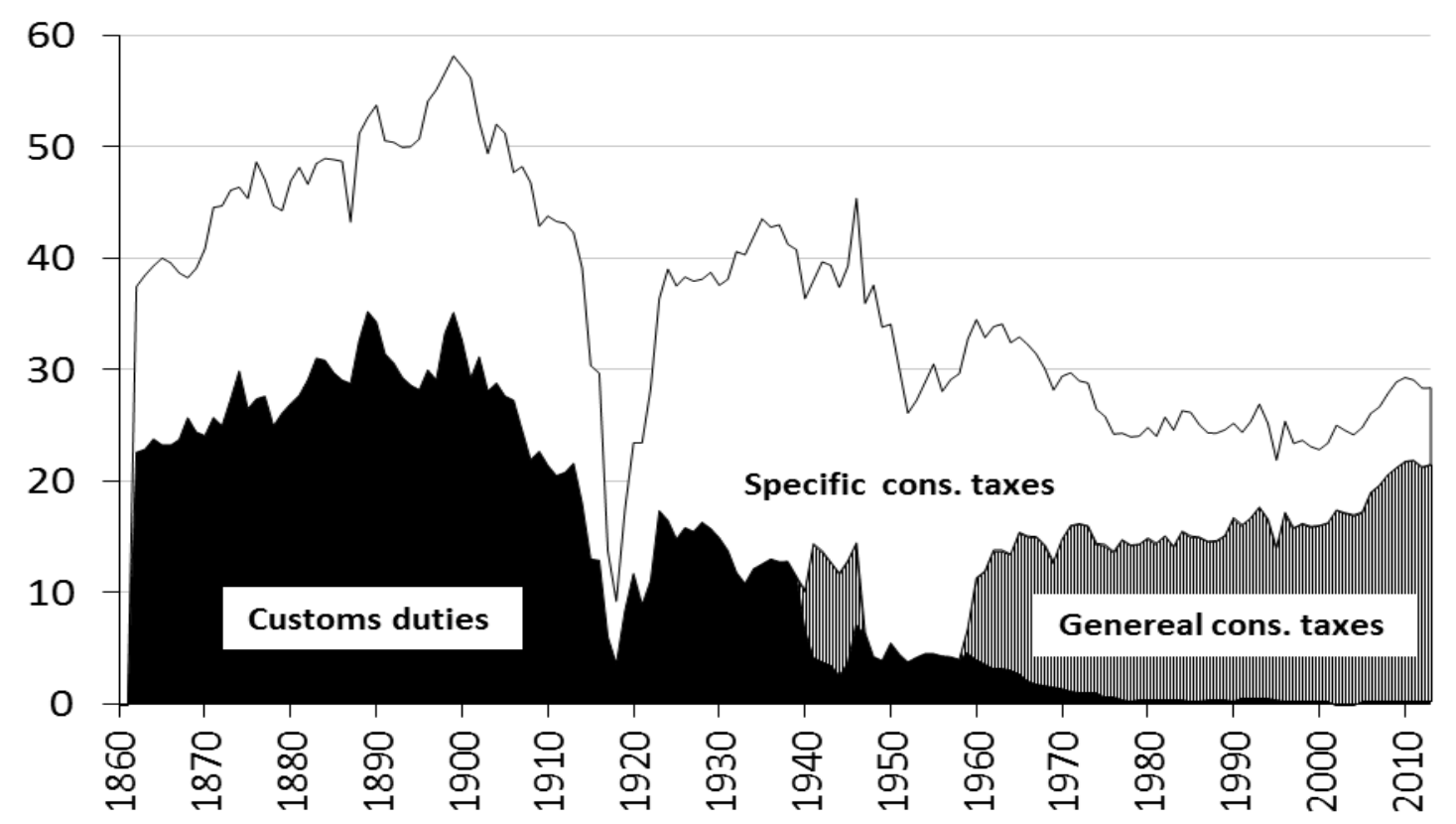

Source: See Figure 1. 


\subsection{Customs duties}

Figure 3 shows that customs duties have been an important source of income for the state government. Customs duties in Sweden have had both fiscal (to raise revenue) and protectionist purposes (to protect vital or infant industries). In the mid-1850s, customs duties decreased internationally, and Sweden followed this trend. By the end of the nineteenth century, political opinions had changed, and customs duties were raised in response to protectionist demands from industry and the general population. ${ }^{9}$ During the 1800 s, up to 50 percent of state revenue consisted of customs duties, and this proportion grew during the late 1800s. However, this share decreased sharply during World War I (together with all other consumption taxes). After World War I, the share of customs duties increased again (to approximately 20 percent) but never returned to pre-war levels.

During World War II, the share of customs duties declined to between five and ten percent. The share increased slightly after the war, but only temporarily. A 1952 tax committee claimed that the main motivation for existing customs duties was to protect Swedish industry. Customs duties were thus no longer understood as a way to generate tax revenue. ${ }^{10}$ Since the 1990 s, the share has been negligible and amounts to less than one percent of state tax revenue and less than one-half of one percent of total tax revenue. As a share of GDP (Figure 5), income from customs duties was at most 2.5 percent (at the end of the nineteenth century).

\footnotetext{
${ }^{9}$ See Gårestad (1987, Chapter 4) for a more thorough discussion of customs duties in the Swedish tax system until World War I.

${ }^{10}$ See, e.g., Rodriguez $(1980,50)$.
} 
Figure 5. Customs duties as a percentage of GDP, 1862-2013.

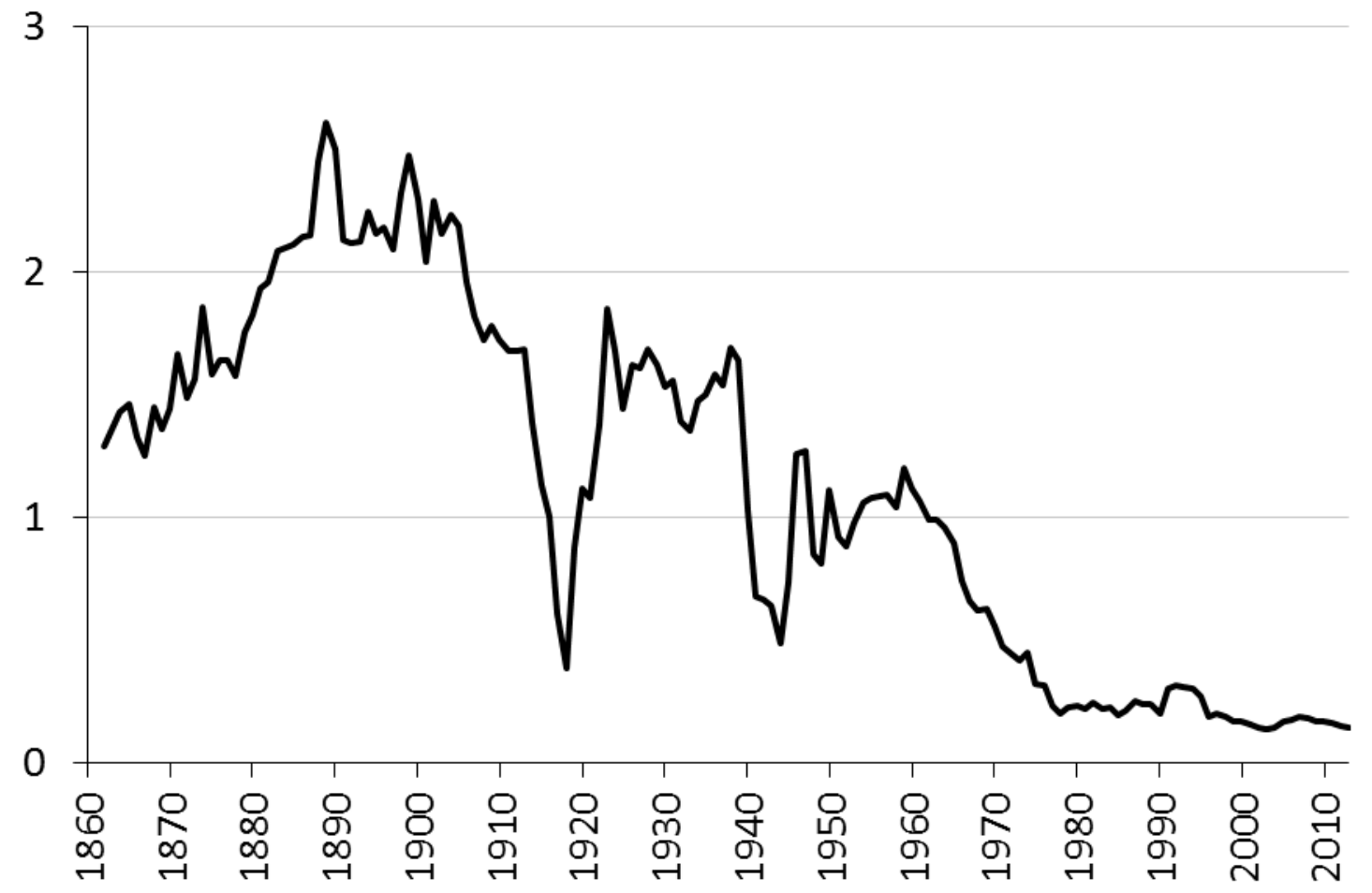

Source: See Figure 2.

\subsection{Specific consumption taxes}

Together with customs duties, specific consumption taxes were the most important tax categories during the nineteenth century. Figure 6 specifies the types of commodities that were taxed and shows that alcohol-related taxes were the most important specific consumption tax until World War I. ${ }^{11}$ Some 25-30 percent of state tax revenue consisted of some form of alcohol tax. ${ }^{12}$ There was also a specific tax on sugar that amounted to ten percent of state tax revenue. Thus, up to 40 percent of state tax revenue was attributable these taxes before World War I. There was a slight upward trend in the share until World War I.

The share of specific consumption taxes decreased dramatically during World War I. After the war, the share quickly reverted to high levels, reaching 30 to 40 percent during the 1920s and peaking at almost 50 percent in the 1930s_clearly higher than before World War

\footnotetext{
${ }^{11}$ The share of total tax revenue follows a similar trajectory, although at a lower level.

${ }^{12}$ Taxes could be levied on both the production and consumption sides. Initially, Swedish vodka (brännvin) was the most important source of the beverage tax. At the beginning of the twentieth century, a specific malt tax (beer) as well as a tax on punsch (Swedish punch) was introduced. Punsch is a sweet arrack-based liqueur that was (and remains) a popular drink among students and teachers in the university cities of Lund and Uppsala. The punsch tax, compared to other taxes at that time, was high, at times reaching 30 percent (of the pre-tax consumer price).
} 
I. ${ }^{13}$ However, the goods that were subject to consumption taxes had changed. Taxes on sugar decreased and ultimately disappeared. Taxes on alcohol decreased (to approximately 15-20 percent) but remained the most important consumption tax base during the interwar period. Two other specific taxes now contributed to a sizeable share of the government budget: taxes on tobacco and taxes on vehicles (automobiles). Tobacco taxes were first introduced during World War I. Their importance was relatively modest at first (a few percentage points, at most). After World War I, tobacco tax revenue increased rapidly to more than ten percent of state tax revenue. A vehicle tax was introduced at the beginning of the 1920 s. $^{14}$ The changing economic structure and the rapid increase in the use of cars made vehicles an important tax base. During the 1930s, the share of this tax base increased to more than ten percent. Vehicle taxes were also progressive, as they mostly affected high-income earners, which made it easier for the population (and politicians) to accept them. Alcohol (and tobacco) taxes were also motivated by public health concerns.

During World War II, specific taxes declined in importance when measured as a share of state tax revenue. However, as a share of GDP, income from specific taxes continued to increase even during World War II (see below), but revenue from other taxes increased more rapidly. Tax revenue from vehicles almost disappeared during World War II. This decrease was offset by the introduction of new taxes on, for instance, “entertainment” (cinemas, theater, concerts etc.), and by raising the tax on tobacco and alcohol.

Following World War II, specific tax revenue as a share of state tax revenue increased but never again reached 50 percent despite higher taxes on many goods and the introduction of new taxes, such as a general consumption tax on electricity (introduced in the 1950s). During the 1960s, the share of specific consumption tax revenue began to decrease rapidly as the sales tax/value added tax was introduced and continuously raised. The importance of alcohol, tobacco and vehicle taxes has continued to decrease since that time. By the end of the period examined, these taxes combined contributed only about five percent of state tax revenue. However, new specific consumption taxes have been introduced in recent decades, mainly related to energy and/or the environment. These taxes constitute almost ten percent of total state tax revenue. Despite these new specific taxes, the share trended downwards after World War II until the turn of the millennium. Increased taxes on energy and activities

\footnotetext{
${ }^{13}$ One reason for the increase during the 1930s was that the Social Democratic Party, which won election in 1932, primarily increased consumption taxes and not income taxes (Steinmo 1993, 86).

${ }^{14}$ The tax on vehicles formally consisted of different parts. One tax was based on the weight of the vehicle. However, there also was a specific tax on tires. It was soon followed by a specific fuel tax. Initially, the revenue from these taxes was supposed to cover the costs of production and maintenance of the road network, i.e., they could be understood as fees, but this connection was gradually attenuated.
} 
detrimental to the environment have reversed the trend. Almost 15 percent of state tax revenue came from specific consumption taxes in 2013.

As a share of GDP (Figure 7), revenue from specific taxes peaked at almost seven percent in the late 1950s. The share increased sharply between the wars (from roughly two percent to four percent). It has decreased since the late 1950s, dropping to roughly three percent by the end of the period. Although revenue from specific consumption taxes constitutes a much smaller share of total tax revenue today compared to the nineteenth century, its share of GDP has more than doubled since the beginning of the period.

Until World War I, sugar and alcohol were the most important tax bases. During the interwar period, alcohol, tobacco and vehicles became the most important. In the postwar period, these tax bases continued to be important but decreased in importance during the 1960s, whereas the importance of taxes on energy and environment increased. As a share of total tax revenue, specific consumption taxes peaked during the 1930s. As a share of GDP, specific consumption taxes peaked in the 1950s. 
Figure 6. Specific consumption taxes as a percentage of state tax revenue, 1862-2013.

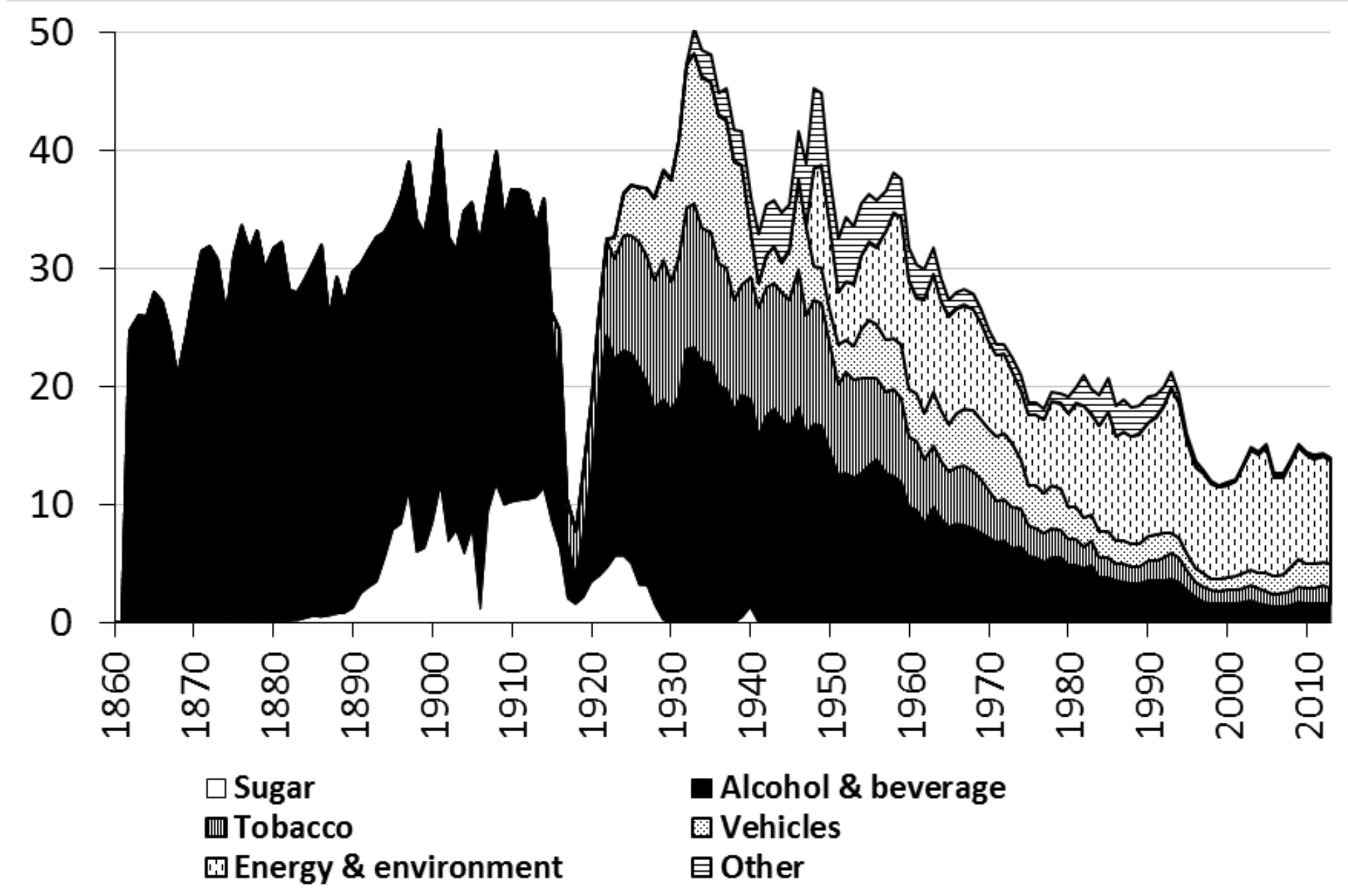

Note: Due to problems with classification, fuel tax is included in "Vehicles" until 1947 and in "Energy \& environment" thereafter. Source: See Figure 1. 
Figure 7. Specific consumption taxes as a percentage of GDP, 1862-2013.

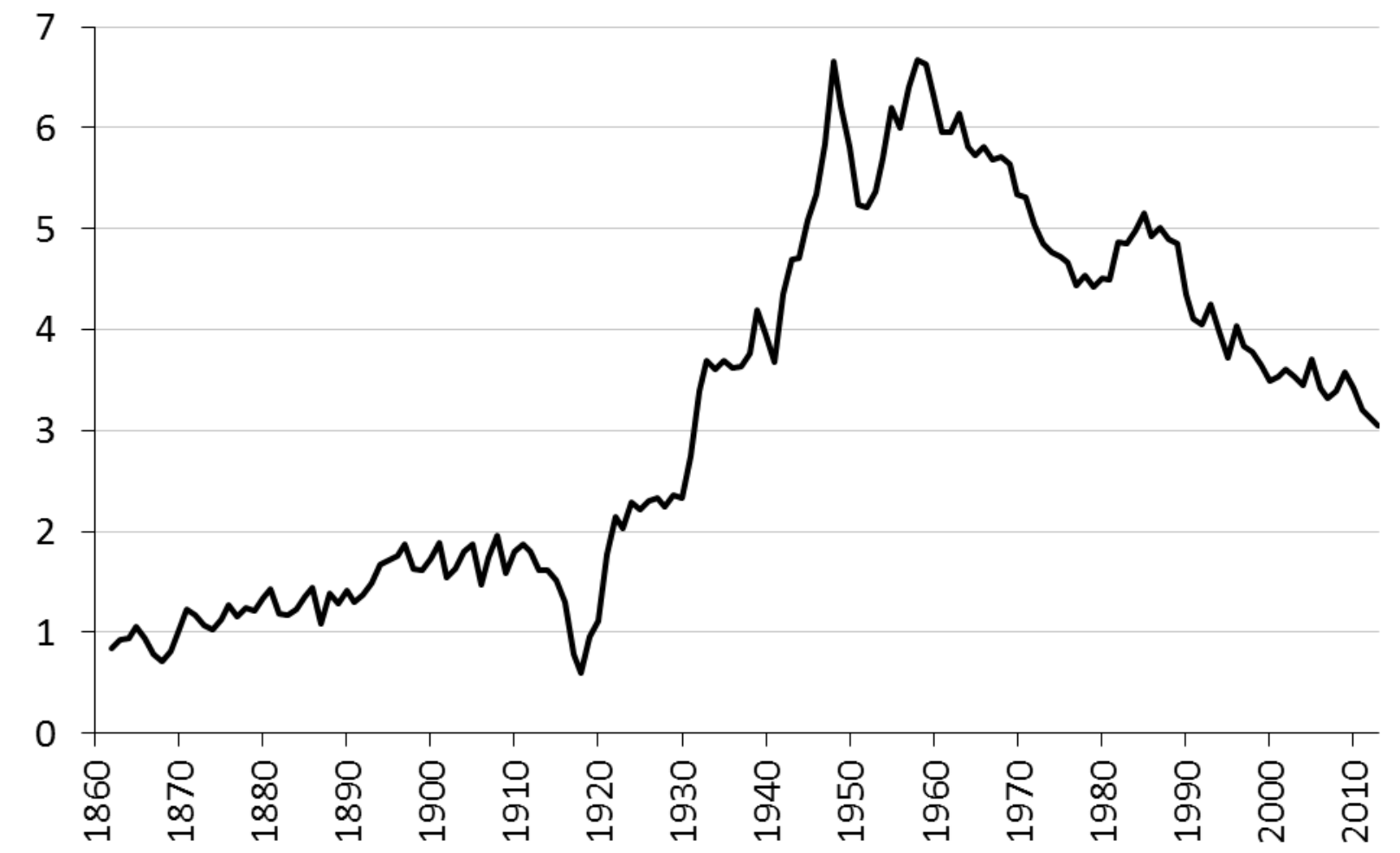

Source: See Figure 2.

\subsection{General consumption taxes}

Figure 3 shows that general consumption taxes are a recent component of the Swedish system compared with other types of taxes. One important objection to general consumption taxes is that they are allegedly regressive, hitting people with low incomes the hardest. A temporary general sales tax was first introduced during World War II, and the tax rate was set at five percent. It contributed more than ten percent of state tax revenue and was high enough to compensate for the drop in customs duties during the war. However, the sales tax was abolished after the war.

After World War II, there was an intense debate among politicians, and several official reports analyzed the expected effect of a general consumption tax. It had become more difficult to raise direct income taxes, and a general consumption tax was considered a viable alternative and complement to regular income taxes. Several arguments were put forward in favor of a general consumption tax. The consumption tax avoided bracket creep, i.e., when price and wage inflation in combination with a progressive tax schedule pushes taxpayers into income brackets with higher marginal tax rates. This problem was severe because, at the time, 
Sweden had a highly progressive income tax system and high inflation. ${ }^{15}$ Consumption taxes were less noticeable to taxpayers (and hence easier to introduce and increase without taxpayer objection) and could also encourage savings. If (part of) the revenue from such a tax was used to support low-income groups, the introduction of a general consumption tax could be acceptable from a distributional perspective. A general consumption tax was easier to collect and required less control compared with a system with highly differentiated tax rates on specific goods and services. A general consumption tax could also be used as a countercyclical mechanism. ${ }^{16}$ After intense debate, a sales tax was introduced in 1960. Initially, the tax rate was four percent, but it was soon raised and reached ten percent in 1963 (see Table 1). As a result, the sales tax share of state tax revenue increased to approximately 20 percent during the 1960s.

In 1969, the sales tax was transformed into a value-added tax (VAT) due to practical and technical reasons. A VAT would not discourage investment, and it paved the way for further increases during the 1970s. The VAT rate almost doubled from ten percent at the beginning of the 1970s to 19 percent at the beginning of the 1980s (see Table 1). The VAT share of state tax revenue continued to increase and varied between 25 and 30 percent during the 1980s. Thus, the revenue from general consumption taxes exceeded the revenue from specific consumption taxes by the beginning of the 1970s, i.e., about ten years after its introduction.

In 1990-1991, a major tax reform was implemented. The VAT was raised to 20 percent, and its base was broadened with tax exemptions for only a handful of services, such as dental care and other social services. Later, the VAT was differentiated with a decreased tax rate on items such as food, hotels, passenger transportation and books (see Table 2). Conversely, some goods and services, such as newspapers, cinemas and concerts, which were previously tax-exempt, began to be taxed, although at a low rate. ${ }^{17}$ The VAT share of state tax revenue has continued to increase and constituted more than 40 percent of state tax revenue at the end of the period examined (Table 3).

Figure 8 depicts general consumption tax revenue as a percentage of GDP. The tax share increased sharply during the 1960s and 1970s. When the sales tax was raised from four to more than nine percent, the share increased from approximately two to four percent. When the VAT increased from ten to 15 percent, its share of GDP increased from four to six percent. It

\footnotetext{
${ }^{15}$ See Du Rietz, Johansson and Stenkula (2015) for a further discussion about the progressive income tax system.

${ }^{16}$ See Rodriguez $(1980,138 f f)$ for a further discussion about indirect taxation and consumption taxes.

${ }^{17}$ At the end of the period, there were three VAT rates: full tax, with a tax rate of 25 percent (20 percent of sales price), and two lower tax rates of 12 (10.71) and six (5.67) percent (see Table 2).
} 
continued to increase until it stabilized around eight percent of GDP in the mid-1980s. In addition, a new increase is discernible at the end of the period examined.

Table 1. Sales tax rates and value added tax rates, 1941-2013.

\begin{tabular}{|c|c|c|}
\hline Year & Percent of sales & \\
\hline 1941 & 5.0 & \\
\hline 1942 & 5.0 & \\
\hline 1943 & 5.0 & \\
\hline 1944 & 5.0 & \\
\hline 1945 & 5.0 & \\
\hline 1946 & 5.0 & \\
\hline 1947-1959 & - & \\
\hline 1960 & 4.0 & \\
\hline 1961 & 4.0 & \\
\hline 1962 & 6.0 & \\
\hline 1963 & 6.0 & \\
\hline 1964 & 6.0 & \\
\hline 1965 & 9.1 & \\
\hline 1966 & 9.1 & \\
\hline 1967 & 10.0 & \\
\hline 1968 & 10.0 & \\
\hline Year & $\begin{array}{l}\text { Percent of } \\
\text { sales price }\end{array}$ & $\begin{array}{c}\text { Percent of } \\
\text { purchase price }\end{array}$ \\
\hline 1969 & 10.0 & 11.1 \\
\hline $1970 *$ & 10.0 & 11.1 \\
\hline 1971 & 15.0 & 17.65 \\
\hline 1972 & 15.0 & 17.65 \\
\hline 1973 & 15.0 & 17.65 \\
\hline $1974 * *$ & 15.0 & 17.65 \\
\hline 1975 & 15.0 & 17.65 \\
\hline 1976 & 15.0 & 17.65 \\
\hline 1977 & 17.1 & 20.63 \\
\hline 1978 & 17.1 & 20.63 \\
\hline 1979 & 17.1 & 20.63 \\
\hline 1980 & 17.1 & 20.63 \\
\hline 1981 & 19.0 & 23.46 \\
\hline 1982 & 17.7 & 21.51 \\
\hline 1983 & 19.0 & 23.46 \\
\hline 1984 & 19.0 & 23.46 \\
\hline 1985 & 19.0 & 23.46 \\
\hline 1986 & 19.0 & 23.46 \\
\hline 1987 & 19.0 & 23.46 \\
\hline 1988 & 19.0 & 23.46 \\
\hline 1989 & 19.0 & 23.46 \\
\hline 1990-2013 & 20.0 & 25.0 \\
\hline
\end{tabular}

Note: The change did not always occur on January 1 each year.

* In 1970, the VAT had previously increased first to 14 and then to 15 percent for some "luxury" commodities (TV sets, cars, etc.)

** In 1974, the VAT was temporarily reduced to 12 (13.64) percent during part of the year.

Source: SOU 2005:57, Rodriguez (1980), Skatteverket (2011). 
Table 2. Differentiated value added tax rates 1991-2013.

\begin{tabular}{|c|c|c|c|c|c|c|c|c|c|c|c|}
\hline & 1991 & 1992 & 1993 & 1994 & 1995 & 1996 & $\begin{array}{r}1997- \\
2000 \\
\end{array}$ & 2001 & $\begin{array}{r}2002- \\
2006 \\
\end{array}$ & $\begin{array}{r}2007- \\
2011 \\
\end{array}$ & $\begin{array}{r}2012- \\
2013 \\
\end{array}$ \\
\hline General & 25 & 25 & 25 & 25 & 25 & 25 & 25 & 25 & 25 & 25 & 25 \\
\hline Food & 25 & 18 & 21 & 21 & 21 & 12 & 12 & 12 & 12 & 12 & 12 \\
\hline Restaurants & 25 & 18 & 21 & 21 & 25 & 25 & 25 & 25 & 25 & 25 & 12 \\
\hline Hotel and camping & 25 & 18 & 21 & 12 & 12 & 12 & 12 & 12 & 12 & 12 & 12 \\
\hline $\begin{array}{l}\text { Passenger } \\
\text { transportation }\end{array}$ & 25 & 18 & 21 & 12 & 12 & 12 & 12 & 6 & 6 & 6 & 6 \\
\hline Transports in skilifts & 25 & 18 & 21 & 12 & 12 & 12 & 12 & 12 & 12 & 6 & 6 \\
\hline Newspapers & 0 & 0 & 0 & 0 & 0 & 6 & 6 & 6 & 6 & 6 & 6 \\
\hline Cinemas & - & - & - & - & - & 6 & 6 & 6 & 6 & 6 & 6 \\
\hline Concerts, opera etc. & - & - & - & - & - & - & 6 & 6 & 6 & 6 & 6 \\
\hline Sports & - & - & - & - & - & - & 6 & 6 & 6 & 6 & 6 \\
\hline Entrance fee zoo & 25 & 25 & 25 & 25 & 25 & 25 & 25 & 6 & 6 & 6 & 6 \\
\hline Books and magazines & 25 & 25 & 25 & 25 & 25 & 25 & 25 & 25 & 6 & 6 & 6 \\
\hline
\end{tabular}

Source: Skatteverket (2013).

Figure 8. General consumption taxes as a percentage of GDP, 1935-2013.

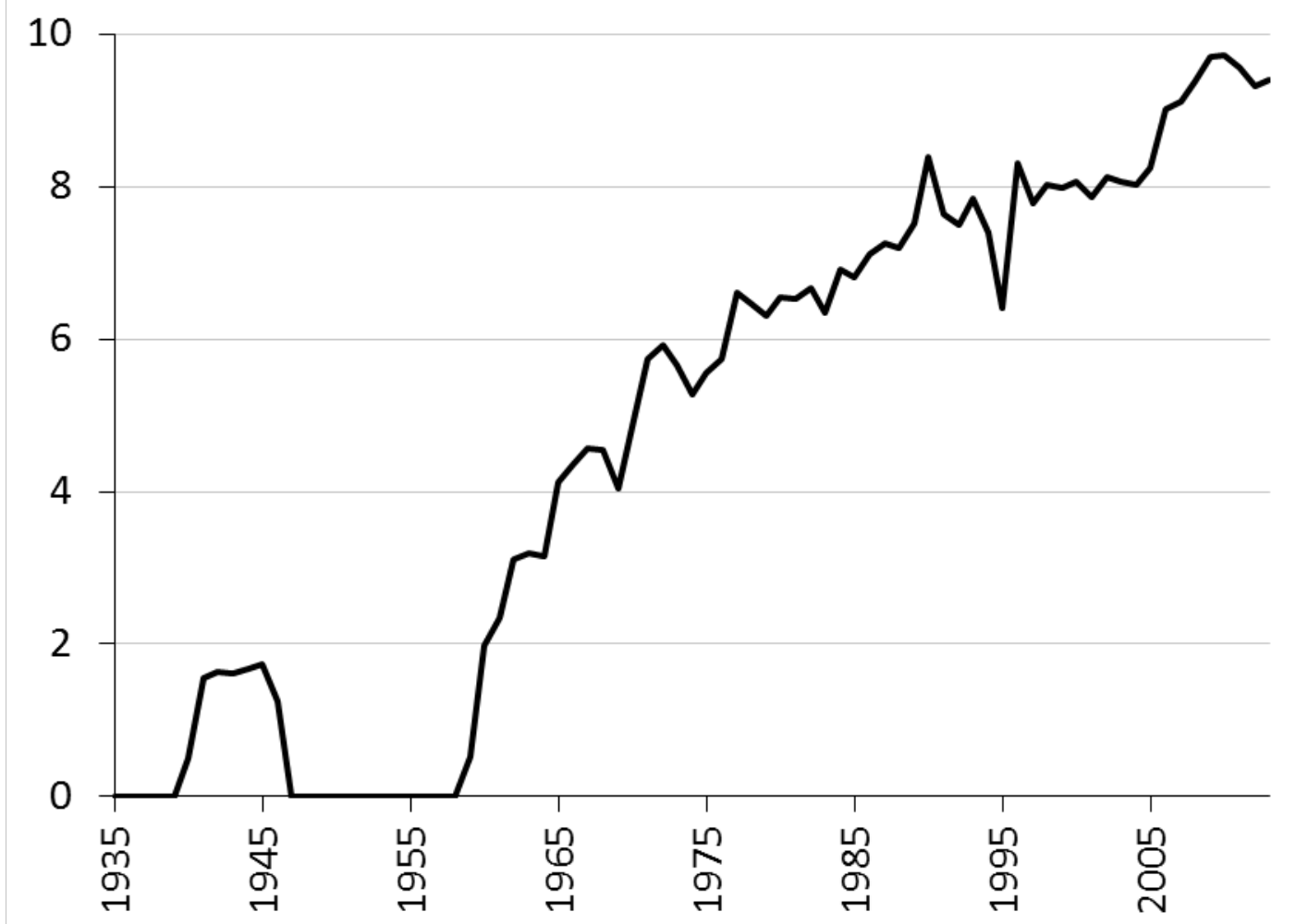

Note: The share was zero percent until 1940.

Source: See Figure 2. 


\section{Conclusion}

This paper has described the evolution of Swedish consumption taxes between 1862 and 2013. The development has been traced for customs duties, general consumption taxes (sales taxes and VAT) and specific consumption taxes (notably, taxes on alcohol, sugar, tobacco, vehicles and energy).

At the beginning of the period, revenue from consumption taxes constituted a substantial (and increasing) share of state and total tax revenue. At the turn of the nineteenth century, it peaked at 85 percent of state tax revenue. Because the state sector remained small, the share of GDP was rather moderate-at approximately three percent. Revenue from customs duties fell precipitously during World War I but swiftly rebounded after the war. Consumption tax revenue as a share of total tax revenue decreased during and after World War II, whereas it decreased as a share of GDP only after the war. Tax revenue from consumption taxes continued to increase during the war, but revenue from other taxes increased even more.

After World War II, consumption taxes as a share of GDP increased substantially. However, only recently is there also an increasing trend as a share of total tax revenue. One reason for this is the importance of social security contributions-introduced at the end of the 1950s - which have increased rapidly. This implied that consumption taxes as a share of tax revenue have been relatively constant although their share of GDP has increased. The highest share of tax revenue (state or total) was reached in or near 1900, whereas the highest share of GDP was realized at the end of the period examined.

With respect to the type of consumption taxes, customs duties were the most important component before World War I and specific consumption taxes assumed this role just before World War I, whereas general consumption taxes have been the most important component since the 1970s.

Customs duties were initially used both as a fiscal device and for protectionist purposes. Customs duties importance increased near the end of the nineteenth century due to more protectionist demands from industry and the population at large. Revenue from custom duties decreased sharply during the World Wars but remained an important source of revenue between the wars. After World War II, its importance fell rapidly and it became fiscally insignificant.

The importance of specific consumption taxes has also decreased. At the beginning of the period, alcohol and sugar were the primary specific consumption taxes. In the interwar period, when specific taxes were the most important consumption tax component, vehicles, alcohol and tobacco were primarily taxed. After World War II, when the importance of specific 
consumption taxes began to decline, the composition changed and environmental and energy taxes now dominate.

General consumption taxes were first introduced temporarily during World War II and then permanently beginning in 1960. The tax rate increased quickly during the 1960s and 1970s, and the share of state tax revenue and of GDP attributable to general consumption taxes increased accordingly. In 1980, general consumption taxes constituted almost 30 percent of state tax revenue and almost seven percent of GDP. Its share has continued to increase at the end of the period examined. 


\section{Appendix}

Table A1. Customs duties, specific consumption taxes and general consumption taxes, percent of state tax revenue.

\begin{tabular}{|c|c|c|c|c|}
\hline Year & Customs duties & Specific taxes & General taxes & Total \\
\hline 1862 & 37.5 & 24.7 & - & 62.2 \\
\hline 1863 & 38.1 & 26.0 & - & 64.1 \\
\hline 1864 & 39.6 & 25.8 & - & 65.4 \\
\hline 1865 & 38.8 & 27.9 & - & 66.7 \\
\hline 1866 & 38.6 & 27.2 & - & 65.7 \\
\hline 1867 & 39.3 & 24.7 & - & 64.0 \\
\hline 1868 & 42.2 & 20.7 & - & 62.9 \\
\hline 1869 & 40.6 & 24.4 & - & 65.0 \\
\hline 1870 & 40.6 & 28.2 & - & 68.8 \\
\hline 1871 & 42.8 & 31.4 & - & 74.3 \\
\hline 1872 & 40.3 & 31.8 & - & 72.1 \\
\hline 1873 & 44.8 & 30.7 & - & 75.6 \\
\hline 1874 & 46.9 & 25.9 & - & 72.8 \\
\hline 1875 & 43.7 & 31.1 & - & 74.8 \\
\hline 1876 & 43.2 & 33.6 & - & 76.8 \\
\hline 1877 & 44.7 & 31.4 & - & 76.1 \\
\hline 1878 & 41.8 & 33.1 & - & 74.9 \\
\hline 1879 & 42.8 & 29.8 & - & 72.7 \\
\hline 1880 & 42.8 & 31.7 & - & 74.6 \\
\hline 1881 & 43.5 & 32.1 & - & 75.6 \\
\hline 1882 & 46.6 & 28.1 & - & 74.7 \\
\hline 1883 & 49.5 & 27.9 & - & 77.4 \\
\hline 1884 & 49.3 & 28.9 & - & 78.2 \\
\hline 1885 & 47.6 & 30.5 & - & 78.1 \\
\hline 1886 & 47.3 & 31.9 & - & 79.2 \\
\hline 1887 & 50.9 & 25.6 & - & 76.6 \\
\hline 1888 & 51.3 & 29.2 & - & 80.5 \\
\hline 1889 & 54.3 & 26.9 & - & 81.2 \\
\hline 1890 & 52.1 & 29.6 & - & 81.7 \\
\hline 1891 & 50.1 & 30.4 & - & 80.5 \\
\hline 1892 & 48.8 & 31.5 & - & 80.3 \\
\hline 1893 & 46.4 & 32.6 & - & 79.0 \\
\hline 1894 & 44.1 & 33.0 & - & 77.1 \\
\hline 1895 & 42.7 & 34.1 & - & 76.8 \\
\hline 1896 & 45.0 & 36.2 & - & 81.1 \\
\hline 1897 & 43.5 & 38.9 & - & 82.4 \\
\hline 1898 & 48.5 & 34.1 & - & 82.6 \\
\hline 1899 & 50.1 & 32.8 & - & 82.9 \\
\hline 1900 & 48.2 & 36.3 & - & 84.4 \\
\hline 1901 & 45.1 & 41.7 & - & 86.8 \\
\hline 1902 & 48.2 & 32.6 & - & 80.7 \\
\hline 1903 & 41.4 & 31.4 & - & 72.8 \\
\hline 1904 & 43.2 & 34.8 & - & 78.0 \\
\hline 1905 & 41.6 & 35.5 & - & 77.1 \\
\hline 1906 & 42.4 & 31.8 & - & 74.2 \\
\hline 1907 & 37.9 & 36.4 & - & 74.3 \\
\hline
\end{tabular}




\begin{tabular}{|c|c|c|c|c|}
\hline Year & Customs duties & Specific taxes & General taxes & Total \\
\hline 1908 & 35.1 & 39.8 & - & 74.9 \\
\hline 1909 & 38.3 & 34.1 & - & 72.4 \\
\hline 1910 & 35.0 & 36.6 & - & 71.6 \\
\hline 1911 & 32.9 & 36.6 & - & 69.5 \\
\hline 1912 & 33.8 & 36.4 & - & 70.1 \\
\hline 1913 & 35.0 & 33.5 & - & 68.5 \\
\hline 1914 & 30.6 & 35.8 & - & 66.4 \\
\hline 1915 & 19.6 & 26.2 & - & 45.8 \\
\hline 1916 & 19.0 & 24.8 & - & 43.8 \\
\hline 1917 & 8.13 & 10.4 & - & 18.5 \\
\hline 1918 & 4.94 & 7.75 & - & 12.7 \\
\hline 1919 & 12.1 & 13.1 & - & 25.2 \\
\hline 1920 & 18.7 & 18.6 & - & 37.3 \\
\hline 1921 & 16.0 & 26.3 & - & 42.3 \\
\hline 1922 & 20.9 & 32.4 & - & 53.3 \\
\hline 1923 & 29.7 & 32.6 & - & 62.3 \\
\hline 1924 & 26.6 & 36.3 & - & 62.9 \\
\hline 1925 & 24.1 & 37.0 & - & 61.2 \\
\hline 1926 & 25.9 & 36.8 & - & 62.7 \\
\hline 1927 & 25.3 & 36.7 & - & 62.0 \\
\hline 1928 & 26.9 & 35.9 & - & 62.8 \\
\hline 1929 & 26.2 & 38.2 & - & 64.4 \\
\hline 1930 & 24.7 & 37.5 & - & 62.2 \\
\hline 1931 & 23.1 & 40.8 & - & 63.9 \\
\hline 1932 & 19.4 & 47.3 & - & 66.7 \\
\hline 1933 & 18.4 & 50.2 & - & 68.7 \\
\hline 1934 & 19.8 & 48.4 & - & 68.2 \\
\hline 1935 & 19.5 & 48.0 & - & 67.4 \\
\hline 1936 & 19.6 & 44.8 & - & 64.4 \\
\hline 1937 & 19.1 & 45.1 & - & 64.2 \\
\hline 1938 & 18.7 & 41.7 & - & 60.4 \\
\hline 1939 & 16.3 & 41.6 & - & 57.8 \\
\hline 1940 & 9.35 & 36.0 & 4.63 & 49.9 \\
\hline 1941 & 6.06 & 32.8 & 13.9 & 52.8 \\
\hline 1942 & 5.39 & 35.4 & 13.4 & 54.1 \\
\hline 1943 & 4.86 & 35.8 & 12.2 & 52.9 \\
\hline 1944 & 3.59 & 34.6 & 12.3 & 50.5 \\
\hline 1945 & 5.11 & 35.3 & 12.1 & 52.5 \\
\hline 1946 & 9.79 & 41.6 & 9.67 & 61.0 \\
\hline 1947 & 8.45 & 38.8 & - & 47.3 \\
\hline 1948 & 5.74 & 45.1 & - & 50.9 \\
\hline 1949 & 5.84 & 44.7 & - & 50.6 \\
\hline 1950 & 7.29 & 38.1 & - & 45.4 \\
\hline 1951 & 5.67 & 32.4 & - & 38.1 \\
\hline 1952 & 5.79 & 34.2 & - & 40.0 \\
\hline 1953 & 6.07 & 33.4 & - & 39.5 \\
\hline 1954 & 6.59 & 35.4 & - & 42.0 \\
\hline 1955 & 6.30 & 36.3 & - & 42.6 \\
\hline 1956 & 6.48 & 35.8 & - & 42.2 \\
\hline 1957 & 6.21 & 36.5 & - & 42.7 \\
\hline
\end{tabular}




\begin{tabular}{|c|c|c|c|c|}
\hline Year & Customs duties & Specific taxes & General taxes & Total \\
\hline 1958 & 5.92 & 38.1 & - & 44.0 \\
\hline 1959 & 6.80 & 37.5 & 2.99 & 47.3 \\
\hline 1960 & 5.61 & 31.7 & 9.92 & 47.2 \\
\hline 1961 & 5.39 & 30.2 & 11.8 & 47.4 \\
\hline 1962 & 4.93 & 29.8 & 15.6 & 50.3 \\
\hline 1963 & 5.10 & 31.7 & 16.5 & 53.2 \\
\hline 1964 & 4.80 & 29.1 & 15.8 & 49.7 \\
\hline 1965 & 4.27 & 27.3 & 19.7 & 51.3 \\
\hline 1966 & 3.56 & 27.9 & 20.9 & 52.4 \\
\hline 1967 & 3.26 & 28.1 & 22.5 & 53.9 \\
\hline 1968 & 3.01 & 27.7 & 22.0 & 52.7 \\
\hline 1969 & 2.94 & 26.5 & 19.0 & 48.4 \\
\hline 1970 & 2.56 & 24.8 & 22.5 & 49.8 \\
\hline 1971 & 2.09 & 23.5 & 25.4 & 51.0 \\
\hline 1972 & 2.07 & 23.5 & 27.6 & 53.3 \\
\hline 1973 & 1.92 & 22.5 & 26.1 & 50.5 \\
\hline 1974 & 1.96 & 20.9 & 23.1 & 45.9 \\
\hline 1975 & 1.27 & 18.6 & 21.9 & 41.7 \\
\hline 1976 & 1.26 & 18.6 & 22.8 & 42.7 \\
\hline 1977 & 0.95 & 18.1 & 26.9 & 45.9 \\
\hline 1978 & 0.86 & 19.5 & 27.9 & 48.2 \\
\hline 1979 & 1.00 & 19.3 & 27.6 & 47.9 \\
\hline 1980 & 0.98 & 19.1 & 27.7 & 47.7 \\
\hline 1981 & 0.97 & 19.9 & 28.9 & 49.8 \\
\hline 1982 & 1.04 & 20.8 & 28.5 & 50.4 \\
\hline 1983 & 0.88 & 19.7 & 25.8 & 46.5 \\
\hline 1984 & 0.86 & 19.2 & 26.7 & 46.8 \\
\hline 1985 & 0.78 & 20.6 & 27.3 & 48.7 \\
\hline 1986 & 0.78 & 18.3 & 26.4 & 45.4 \\
\hline 1987 & 0.94 & 18.8 & 27.3 & 47.0 \\
\hline 1988 & 0.89 & 18.2 & 26.7 & 45.8 \\
\hline 1989 & 0.90 & 18.3 & 28.3 & 47.5 \\
\hline 1990 & 0.89 & 19.1 & 36.8 & 56.8 \\
\hline 1991 & 1.43 & 19.3 & 35.8 & 56.5 \\
\hline 1992 & 1.55 & 19.8 & 36.7 & 58.0 \\
\hline 1993 & 1.53 & 21.2 & 39.0 & 61.8 \\
\hline 1994 & 1.47 & 19.3 & 35.9 & 56.7 \\
\hline 1995 & 1.16 & 16.0 & 27.5 & 44.6 \\
\hline 1996 & 0.63 & 13.6 & 28.0 & 42.3 \\
\hline 1997 & 0.66 & 12.9 & 26.1 & 39.6 \\
\hline 1998 & 0.59 & 12.0 & 25.4 & 38.0 \\
\hline 1999 & 0.53 & 11.6 & 25.4 & 37.5 \\
\hline 2000 & 0.57 & 11.8 & 27.2 & 39.5 \\
\hline 2001 & 0.53 & 12.1 & 27.0 & 39.7 \\
\hline 2002 & 0.53 & 13.4 & 30.1 & 44.0 \\
\hline 2003 & 0.57 & 14.8 & 33.7 & 49.0 \\
\hline 2004 & 0.59 & 14.4 & 33.5 & 48.5 \\
\hline 2005 & 0.68 & 15.1 & 33.5 & 49.2 \\
\hline 2006 & 0.65 & 12.6 & 33.2 & 46.4 \\
\hline 2007 & 0.71 & 12.6 & 34.5 & 47.8 \\
\hline
\end{tabular}




\begin{tabular}{ccccc}
\hline Year & Customs duties & Specific taxes & General taxes & Total \\
\hline 2008 & 0.75 & 13.8 & 38.2 & 52.7 \\
2009 & 0.70 & 15.1 & 41.0 & 56.8 \\
2010 & 0.72 & 14.5 & 41.1 & 56.3 \\
2011 & 0.72 & 14.1 & 42.0 & 56.8 \\
2012 & 0.68 & 14.3 & 42.6 & 57.6 \\
2013 & 0.65 & 13.8 & 42.7 & 57.1 \\
\hline
\end{tabular}

Source: See Figure 1. 
Table A2. Customs duties, specific consumption taxes and general consumption taxes, percent of total tax revenue.

\begin{tabular}{|c|c|c|c|c|}
\hline Year & Customs duties & Specific taxes & General taxes & Total \\
\hline 1862 & 22.6 & 14.9 & - & 37.4 \\
\hline 1863 & 22.9 & 15.6 & - & 38.5 \\
\hline 1864 & 23.8 & 15.5 & - & 39.3 \\
\hline 1865 & 23.3 & 16.8 & - & 40.0 \\
\hline 1866 & 23.2 & 16.4 & - & 39.6 \\
\hline 1867 & 23.7 & 15.0 & - & 38.7 \\
\hline 1868 & 25.7 & 12.6 & - & 38.2 \\
\hline 1869 & 24.4 & 14.7 & - & 39.1 \\
\hline 1870 & 24.1 & 16.7 & - & 40.8 \\
\hline 1871 & 25.7 & 18.8 & - & 44.5 \\
\hline 1872 & 25.0 & 19.7 & - & 44.7 \\
\hline 1873 & 27.3 & 18.7 & - & 46.1 \\
\hline 1874 & 29.9 & 16.5 & - & 46.4 \\
\hline 1875 & 26.5 & 18.9 & - & 45.4 \\
\hline 1876 & 27.4 & 21.3 & - & 48.6 \\
\hline 1877 & 27.6 & 19.4 & - & 47.0 \\
\hline 1878 & 24.9 & 19.8 & - & 44.7 \\
\hline 1879 & 26.1 & 18.2 & - & 44.3 \\
\hline 1880 & 27.0 & 20.0 & - & 46.9 \\
\hline 1881 & 27.7 & 20.5 & - & 48.2 \\
\hline 1882 & 29.1 & 17.6 & - & 46.6 \\
\hline 1883 & 31.0 & 17.5 & - & 48.5 \\
\hline 1884 & 30.8 & 18.1 & - & 48.9 \\
\hline 1885 & 29.8 & 19.1 & - & 48.8 \\
\hline 1886 & 29.1 & 19.6 & - & 48.7 \\
\hline 1887 & 28.8 & 14.5 & - & 43.2 \\
\hline 1888 & 32.6 & 18.5 & - & 51.2 \\
\hline 1889 & 35.2 & 17.4 & - & 52.6 \\
\hline 1890 & 34.3 & 19.4 & - & 53.7 \\
\hline 1891 & 31.4 & 19.1 & - & 50.5 \\
\hline 1892 & 30.6 & 19.8 & - & 50.4 \\
\hline 1893 & 29.3 & 20.6 & - & 49.9 \\
\hline 1894 & 28.6 & 21.4 & - & 50.0 \\
\hline 1895 & 28.2 & 22.5 & - & 50.7 \\
\hline 1896 & 30.0 & 24.1 & - & 54.1 \\
\hline 1897 & 29.1 & 26.0 & - & 55.1 \\
\hline 1898 & 33.3 & 23.3 & - & 56.6 \\
\hline 1899 & 35.1 & 23.0 & - & 58.1 \\
\hline 1900 & 32.6 & 24.6 & - & 57.2 \\
\hline 1901 & 29.2 & 27.0 & - & 56.2 \\
\hline 1902 & 31.1 & 21.1 & - & 52.2 \\
\hline 1903 & 28.1 & 21.3 & - & 49.4 \\
\hline 1904 & 28.8 & 23.2 & - & 52.0 \\
\hline 1905 & 27.6 & 23.6 & - & 51.2 \\
\hline 1906 & 27.3 & 20.4 & - & 47.7 \\
\hline 1907 & 24.6 & 23.6 & - & 48.2 \\
\hline 1908 & 21.9 & 24.9 & - & 46.8 \\
\hline 1909 & 22.7 & 20.2 & - & 42.9 \\
\hline
\end{tabular}




\begin{tabular}{|c|c|c|c|c|}
\hline Year & Customs duties & Specific taxes & General taxes & Total \\
\hline 1910 & 21.4 & 22.4 & - & 43.8 \\
\hline 1911 & 20.5 & 22.8 & - & 43.3 \\
\hline 1912 & 20.8 & 22.4 & - & 43.1 \\
\hline 1913 & 21.6 & 20.7 & - & 42.3 \\
\hline 1914 & 18.0 & 21.1 & - & 39.1 \\
\hline 1915 & 13.0 & 17.4 & - & 30.4 \\
\hline 1916 & 12.9 & 16.8 & - & 29.7 \\
\hline 1917 & 6.04 & 7.72 & - & 13.8 \\
\hline 1918 & 3.59 & 5.62 & - & 9.21 \\
\hline 1919 & 8.35 & 9.08 & - & 17.4 \\
\hline 1920 & 11.7 & 11.7 & - & 23.4 \\
\hline 1921 & 8.88 & 14.6 & - & 23.4 \\
\hline 1922 & 11.1 & 17.2 & - & 28.3 \\
\hline 1923 & 17.3 & 19.0 & - & 36.4 \\
\hline 1924 & 16.5 & 22.5 & - & 39.0 \\
\hline 1925 & 14.8 & 22.7 & - & 37.5 \\
\hline 1926 & 15.8 & 22.5 & - & 38.3 \\
\hline 1927 & 15.5 & 22.5 & - & 37.9 \\
\hline 1928 & 16.3 & 21.8 & - & 38.1 \\
\hline 1929 & 15.7 & 23.0 & - & 38.7 \\
\hline 1930 & 14.9 & 22.7 & - & 37.6 \\
\hline 1931 & 13.8 & 24.3 & - & 38.1 \\
\hline 1932 & 11.8 & 28.8 & - & 40.6 \\
\hline 1933 & 10.8 & 29.5 & - & 40.3 \\
\hline 1934 & 12.1 & 29.8 & - & 41.9 \\
\hline 1935 & 12.6 & 31.0 & - & 43.5 \\
\hline 1936 & 13.0 & 29.8 & - & 42.8 \\
\hline 1937 & 12.8 & 30.2 & - & 43.0 \\
\hline 1938 & 12.8 & 28.5 & - & 41.2 \\
\hline 1939 & 11.5 & 29.3 & - & 40.8 \\
\hline 1940 & 6.81 & 26.2 & 3.37 & 36.4 \\
\hline 1941 & 4.37 & 23.6 & 10.0 & 38.0 \\
\hline 1942 & 3.95 & 25.9 & 9.79 & 39.7 \\
\hline 1943 & 3.62 & 26.6 & 9.12 & 39.4 \\
\hline 1944 & 2.66 & 25.6 & 9.08 & 37.4 \\
\hline 1945 & 3.83 & 26.4 & 9.03 & 39.3 \\
\hline 1946 & 7.27 & 30.9 & 7.19 & 45.4 \\
\hline 1947 & 6.43 & 29.5 & - & 35.9 \\
\hline 1948 & 4.24 & 33.3 & - & 37.6 \\
\hline 1949 & 3.91 & 29.9 & - & 33.8 \\
\hline 1950 & 5.47 & 28.6 & - & 34.1 \\
\hline 1951 & 4.48 & 25.6 & - & 30.1 \\
\hline 1952 & 3.77 & 22.3 & - & 26.1 \\
\hline 1953 & 4.19 & 23.0 & - & 27.2 \\
\hline 1954 & 4.53 & 24.3 & - & 28.8 \\
\hline 1955 & 4.52 & 26.0 & - & 30.5 \\
\hline 1956 & 4.30 & 23.7 & - & 28.0 \\
\hline 1957 & 4.24 & 24.9 & - & 29.1 \\
\hline 1958 & 3.99 & 25.6 & - & 29.6 \\
\hline 1959 & 4.71 & 26.0 & 2.07 & 32.7 \\
\hline
\end{tabular}




\begin{tabular}{|c|c|c|c|c|}
\hline Year & Customs duties & Specific taxes & General taxes & Total \\
\hline 1960 & 4.09 & 23.2 & 7.24 & 34.5 \\
\hline 1961 & 3.73 & 20.9 & 8.20 & 32.9 \\
\hline 1962 & 3.32 & 20.1 & 10.5 & 33.9 \\
\hline 1963 & 3.27 & 20.3 & 10.5 & 34.1 \\
\hline 1964 & 3.13 & 19.0 & 10.3 & 32.4 \\
\hline 1965 & 2.74 & 17.5 & 12.7 & 32.9 \\
\hline 1966 & 2.19 & 17.2 & 12.9 & 32.2 \\
\hline 1967 & 1.89 & 16.4 & 13.1 & 31.4 \\
\hline 1968 & 1.72 & 15.8 & 12.5 & 30.0 \\
\hline 1969 & 1.71 & 15.4 & 11.0 & 28.2 \\
\hline 1970 & 1.51 & 14.6 & 13.3 & 29.4 \\
\hline 1971 & 1.22 & 13.7 & 14.8 & 29.7 \\
\hline 1972 & 1.13 & 12.8 & 15.0 & 29.0 \\
\hline 1973 & 1.09 & 12.8 & 14.9 & 28.8 \\
\hline 1974 & 1.13 & 12.0 & 13.3 & 26.4 \\
\hline 1975 & 0.79 & 11.5 & 13.5 & 25.8 \\
\hline 1976 & 0.71 & 10.5 & 13.0 & 24.2 \\
\hline 1977 & 0.50 & 9.55 & 14.2 & 24.3 \\
\hline 1978 & 0.43 & 9.70 & 13.8 & 24.0 \\
\hline 1979 & 0.50 & 9.70 & 13.8 & 24.0 \\
\hline 1980 & 0.51 & 9.91 & 14.4 & 24.8 \\
\hline 1981 & 0.47 & 9.60 & 14.0 & 24.0 \\
\hline 1982 & 0.53 & 10.6 & 14.6 & 25.7 \\
\hline 1983 & 0.47 & 10.4 & 13.7 & 24.6 \\
\hline 1984 & 0.48 & 10.8 & 15.0 & 26.3 \\
\hline 1985 & 0.42 & 11.1 & 14.7 & 26.2 \\
\hline 1986 & 0.43 & 10.1 & 14.5 & 25.1 \\
\hline 1987 & 0.49 & 9.72 & 14.1 & 24.3 \\
\hline 1988 & 0.47 & 9.65 & 14.2 & 24.3 \\
\hline 1989 & 0.47 & 9.48 & 14.7 & 24.6 \\
\hline 1990 & 0.39 & 8.46 & 16.3 & 25.2 \\
\hline 1991 & 0.62 & 8.31 & 15.4 & 24.4 \\
\hline 1992 & 0.68 & 8.65 & 16.0 & 25.3 \\
\hline 1993 & 0.66 & 9.23 & 17.0 & 26.9 \\
\hline 1994 & 0.65 & 8.58 & 15.9 & 25.2 \\
\hline 1995 & 0.57 & 7.84 & 13.5 & 21.9 \\
\hline 1996 & 0.38 & 8.19 & 16.8 & 25.4 \\
\hline 1997 & 0.39 & 7.58 & 15.4 & 23.4 \\
\hline 1998 & 0.37 & 7.46 & 15.8 & 23.7 \\
\hline 1999 & 0.32 & 7.15 & 15.6 & 23.1 \\
\hline 2000 & 0.33 & 6.80 & 15.7 & 22.8 \\
\hline 2001 & 0.31 & 7.16 & 15.9 & 23.4 \\
\hline 2002 & 0.30 & 7.61 & 17.1 & 25.0 \\
\hline 2003 & 0.28 & 7.39 & 16.9 & 24.5 \\
\hline 2004 & 0.30 & 7.18 & 16.7 & 24.2 \\
\hline 2005 & 0.34 & 7.59 & 16.9 & 24.8 \\
\hline 2006 & 0.36 & 7.08 & 18.6 & 26.1 \\
\hline 2007 & 0.40 & 7.02 & 19.2 & 26.6 \\
\hline 2008 & 0.39 & 7.29 & 20.2 & 27.9 \\
\hline 2009 & 0.36 & 7.68 & 20.9 & 28.9 \\
\hline
\end{tabular}




\begin{tabular}{ccccc}
\hline Year & Customs duties & Specific taxes & General taxes & Total \\
\hline 2010 & 0.37 & 7.52 & 21.4 & 29.3 \\
2011 & 0.37 & 7.21 & 21.5 & 29.1 \\
2012 & 0.33 & 7.05 & 21.0 & 28.3 \\
2013 & 0.32 & 6.86 & 21.2 & 28.4 \\
\hline
\end{tabular}

Source: See Figure 1. 
Table A3. Customs duties, specific consumption taxes and general consumption taxes, percent of GDP.

\begin{tabular}{|c|c|c|c|c|}
\hline Year & Customs duties & Specific taxes & General taxes & Total \\
\hline 1862 & 1.29 & 0.85 & - & 2.13 \\
\hline 1863 & 1.36 & 0.93 & - & 2.28 \\
\hline 1864 & 1.43 & 0.93 & - & 2.36 \\
\hline 1865 & 1.46 & 1.05 & - & 2.51 \\
\hline 1866 & 1.33 & 0.94 & - & 2.26 \\
\hline 1867 & 1.25 & 0.79 & - & 2.04 \\
\hline 1868 & 1.45 & 0.71 & - & 2.16 \\
\hline 1869 & 1.36 & 0.82 & - & 2.18 \\
\hline 1870 & 1.44 & 1.00 & - & 2.44 \\
\hline 1871 & 1.66 & 1.22 & - & 2.88 \\
\hline 1872 & 1.49 & 1.18 & - & 2.67 \\
\hline 1873 & 1.56 & 1.07 & - & 2.64 \\
\hline 1874 & 1.86 & 1.03 & - & 2.88 \\
\hline 1875 & 1.58 & 1.12 & - & 2.70 \\
\hline 1876 & 1.64 & 1.27 & - & 2.91 \\
\hline 1877 & 1.64 & 1.15 & - & 2.79 \\
\hline 1878 & 1.57 & 1.25 & - & 2.82 \\
\hline 1879 & 1.75 & 1.22 & - & 2.97 \\
\hline 1880 & 1.82 & 1.35 & - & 3.17 \\
\hline 1881 & 1.93 & 1.43 & - & 3.36 \\
\hline 1882 & 1.96 & 1.18 & - & 3.14 \\
\hline 1883 & 2.08 & 1.17 & - & 3.26 \\
\hline 1884 & 2.10 & 1.23 & - & 3.33 \\
\hline 1885 & 2.11 & 1.35 & - & 3.46 \\
\hline 1886 & 2.14 & 1.45 & - & 3.59 \\
\hline 1887 & 2.15 & 1.08 & - & 3.23 \\
\hline 1888 & 2.45 & 1.39 & - & 3.84 \\
\hline 1889 & 2.61 & 1.29 & - & 3.90 \\
\hline 1890 & 2.50 & 1.42 & - & 3.92 \\
\hline 1891 & 2.13 & 1.29 & - & 3.42 \\
\hline 1892 & 2.12 & 1.37 & - & 3.49 \\
\hline 1893 & 2.12 & 1.49 & - & 3.62 \\
\hline 1894 & 2.24 & 1.68 & - & 3.92 \\
\hline 1895 & 2.15 & 1.72 & - & 3.87 \\
\hline 1896 & 2.18 & 1.76 & - & 3.94 \\
\hline 1897 & 2.09 & 1.87 & - & 3.96 \\
\hline 1898 & 2.32 & 1.63 & - & 3.95 \\
\hline 1899 & 2.47 & 1.62 & - & 4.09 \\
\hline 1900 & 2.30 & 1.73 & - & 4.03 \\
\hline 1901 & 2.04 & 1.89 & - & 3.93 \\
\hline 1902 & 2.29 & 1.55 & - & 3.84 \\
\hline 1903 & 2.15 & 1.63 & - & 3.79 \\
\hline 1904 & 2.23 & 1.80 & - & 4.03 \\
\hline 1905 & 2.19 & 1.87 & - & 4.06 \\
\hline 1906 & 1.96 & 1.47 & - & 3.42 \\
\hline 1907 & 1.81 & 1.75 & - & 3.56 \\
\hline 1908 & 1.72 & 1.96 & - & 3.68 \\
\hline 1909 & 1.78 & 1.58 & - & 3.36 \\
\hline
\end{tabular}




\begin{tabular}{|c|c|c|c|c|}
\hline Year & Customs duties & Specific taxes & General taxes & Total \\
\hline 1910 & 1.72 & 1.80 & - & 3.52 \\
\hline 1911 & 1.68 & 1.87 & - & 3.54 \\
\hline 1912 & 1.68 & 1.80 & - & 3.48 \\
\hline 1913 & 1.69 & 1.61 & - & 3.30 \\
\hline 1914 & 1.38 & 1.62 & - & 3.00 \\
\hline 1915 & 1.13 & 1.51 & - & 2.64 \\
\hline 1916 & 1.00 & 1.30 & - & 2.30 \\
\hline 1917 & 0.61 & 0.78 & - & 1.38 \\
\hline 1918 & 0.38 & 0.60 & - & 0.99 \\
\hline 1919 & 0.87 & 0.95 & - & 1.82 \\
\hline 1920 & 1.12 & 1.12 & - & 2.23 \\
\hline 1921 & 1.08 & 1.77 & - & 2.84 \\
\hline 1922 & 1.38 & 2.14 & - & 3.52 \\
\hline 1923 & 1.85 & 2.03 & - & 3.88 \\
\hline 1924 & 1.68 & 2.29 & - & 3.97 \\
\hline 1925 & 1.44 & 2.22 & - & 3.66 \\
\hline 1926 & 1.62 & 2.30 & - & 3.92 \\
\hline 1927 & 1.61 & 2.33 & - & 3.94 \\
\hline 1928 & 1.68 & 2.25 & - & 3.94 \\
\hline 1929 & 1.62 & 2.36 & - & 3.98 \\
\hline 1930 & 1.53 & 2.33 & - & 3.86 \\
\hline 1931 & 1.55 & 2.74 & - & 4.30 \\
\hline 1932 & 1.39 & 3.39 & - & 4.78 \\
\hline 1933 & 1.35 & 3.69 & - & 5.04 \\
\hline 1934 & 1.47 & 3.61 & - & 5.08 \\
\hline 1935 & 1.50 & 3.69 & - & 5.18 \\
\hline 1936 & 1.58 & 3.62 & - & 5.21 \\
\hline 1937 & 1.53 & 3.63 & - & 5.16 \\
\hline 1938 & 1.69 & 3.76 & - & 5.45 \\
\hline 1939 & 1.64 & 4.19 & - & 5.83 \\
\hline 1940 & 1.03 & 3.96 & 0.51 & 5.49 \\
\hline 1941 & 0.68 & 3.68 & 1.56 & 5.92 \\
\hline 1942 & 0.66 & 4.35 & 1.64 & 6.65 \\
\hline 1943 & 0.64 & 4.69 & 1.61 & 6.94 \\
\hline 1944 & 0.49 & 4.71 & 1.67 & 6.87 \\
\hline 1945 & 0.74 & 5.08 & 1.74 & 7.56 \\
\hline 1946 & 1.26 & 5.34 & 1.24 & 7.84 \\
\hline 1947 & 1.27 & 5.84 & - & 7.11 \\
\hline 1948 & 0.85 & 6.67 & - & 7.51 \\
\hline 1949 & 0.81 & 6.22 & - & 7.03 \\
\hline 1950 & 1.11 & 5.81 & - & 6.92 \\
\hline 1951 & 0.92 & 5.24 & - & 6.16 \\
\hline 1952 & 0.88 & 5.21 & - & 6.09 \\
\hline 1953 & 0.97 & 5.36 & - & 6.34 \\
\hline 1954 & 1.06 & 5.69 & - & 6.75 \\
\hline 1955 & 1.08 & 6.20 & - & 7.28 \\
\hline 1956 & 1.09 & 6.00 & - & 7.09 \\
\hline 1957 & 1.09 & 6.40 & - & 7.50 \\
\hline 1958 & 1.04 & 6.67 & - & 7.71 \\
\hline 1959 & 1.20 & 6.63 & 0.53 & 8.36 \\
\hline
\end{tabular}




\begin{tabular}{|c|c|c|c|c|}
\hline Year & Customs duties & Specific taxes & General taxes & Total \\
\hline 1960 & 1.12 & 6.33 & 1.98 & 9.43 \\
\hline 1961 & 1.06 & 5.96 & 2.34 & 9.37 \\
\hline 1962 & 0.99 & 5.96 & 3.12 & 10.1 \\
\hline 1963 & 0.99 & 6.15 & 3.20 & 10.3 \\
\hline 1964 & 0.96 & 5.82 & 3.16 & 9.94 \\
\hline 1965 & 0.89 & 5.72 & 4.13 & 10.7 \\
\hline 1966 & 0.74 & 5.82 & 4.36 & 10.9 \\
\hline 1967 & 0.66 & 5.69 & 4.56 & 10.9 \\
\hline 1968 & 0.62 & 5.72 & 4.54 & 10.9 \\
\hline 1969 & 0.63 & 5.64 & 4.04 & 10.3 \\
\hline 1970 & 0.55 & 5.34 & 4.85 & 10.8 \\
\hline 1971 & 0.47 & 5.31 & 5.74 & 11.5 \\
\hline 1972 & 0.44 & 5.03 & 5.91 & 11.4 \\
\hline 1973 & 0.41 & 4.86 & 5.65 & 10.9 \\
\hline 1974 & 0.45 & 4.77 & 5.27 & 10.5 \\
\hline 1975 & 0.32 & 4.73 & 5.57 & 10.6 \\
\hline 1976 & 0.32 & 4.67 & 5.75 & 10.7 \\
\hline 1977 & 0.23 & 4.43 & 6.61 & 11.3 \\
\hline 1978 & 0.20 & 4.54 & 6.48 & 11.2 \\
\hline 1979 & 0.23 & 4.42 & 6.31 & 11.0 \\
\hline 1980 & 0.23 & 4.51 & 6.54 & 11.3 \\
\hline 1981 & 0.22 & 4.49 & 6.53 & 11.3 \\
\hline 1982 & 0.24 & 4.87 & 6.66 & 11.8 \\
\hline 1983 & 0.22 & 4.85 & 6.35 & 11.5 \\
\hline 1984 & 0.22 & 4.98 & 6.92 & 12.2 \\
\hline 1985 & 0.19 & 5.16 & 6.82 & 12.2 \\
\hline 1986 & 0.21 & 4.92 & 7.11 & 12.3 \\
\hline 1987 & 0.25 & 5.01 & 7.26 & 12.5 \\
\hline 1988 & 0.24 & 4.90 & 7.20 & 12.4 \\
\hline 1989 & 0.24 & 4.86 & 7.52 & 12.6 \\
\hline 1990 & 0.20 & 4.35 & 8.39 & 13.0 \\
\hline 1991 & 0.30 & 4.11 & 7.63 & 12.1 \\
\hline 1992 & 0.32 & 4.05 & 7.50 & 11.9 \\
\hline 1993 & 0.31 & 4.26 & 7.84 & 12.4 \\
\hline 1994 & 0.30 & 3.97 & 7.39 & 11.7 \\
\hline 1995 & 0.27 & 3.72 & 6.40 & 10.4 \\
\hline 1996 & 0.19 & 4.04 & 8.30 & 12.5 \\
\hline 1997 & 0.20 & 3.83 & 7.77 & 11.8 \\
\hline 1998 & 0.19 & 3.78 & 8.03 & 12.0 \\
\hline 1999 & 0.17 & 3.65 & 7.98 & 11.8 \\
\hline 2000 & 0.17 & 3.50 & 8.07 & 11.7 \\
\hline 2001 & 0.16 & 3.54 & 7.87 & 11.6 \\
\hline 2002 & 0.14 & 3.61 & 8.12 & 11.9 \\
\hline 2003 & 0.14 & 3.53 & 8.06 & 11.7 \\
\hline 2004 & 0.14 & 3.45 & 8.01 & 11.6 \\
\hline 2005 & 0.17 & 3.71 & 8.25 & 12.1 \\
\hline 2006 & 0.18 & 3.42 & 9.01 & 12.6 \\
\hline 2007 & 0.19 & 3.32 & 9.11 & 12.7 \\
\hline 2008 & 0.18 & 3.39 & 9.37 & 13.0 \\
\hline 2009 & 0.17 & 3.58 & 9.71 & 13.5 \\
\hline
\end{tabular}




\begin{tabular}{ccccc}
\hline Year & Customs duties & Specific taxes & General taxes & Total \\
\hline 2010 & 0.17 & 3.42 & 9.72 & 13.3 \\
2011 & 0.16 & 3.20 & 9.55 & 12.9 \\
2012 & 0.15 & 3.13 & 9.31 & 12.6 \\
2013 & 0.14 & 3.04 & 9.39 & 12.6 \\
\hline
\end{tabular}

Source: See Figure 2. 
Table A4. Specific consumption taxes, percent of state tax revenue.

\begin{tabular}{|c|c|c|c|c|c|c|}
\hline Year & $\begin{array}{l}\text { Alcohol \& } \\
\text { beverages }\end{array}$ & Sugar & Tobacco & Vehicles & $\begin{array}{c}\text { Energy and } \\
\text { environment }\end{array}$ & Other \\
\hline 1862 & 24.7 & - & - & - & - & - \\
\hline 1863 & 26.0 & - & - & - & - & - \\
\hline 1864 & 25.8 & - & - & - & - & - \\
\hline 1865 & 27.9 & - & - & - & - & - \\
\hline 1866 & 27.2 & - & - & - & - & - \\
\hline 1867 & 24.7 & - & - & - & - & - \\
\hline 1868 & 20.7 & - & - & - & - & - \\
\hline 1869 & 24.4 & - & - & - & - & - \\
\hline 1870 & 28.2 & - & - & - & - & - \\
\hline 1871 & 31.4 & - & - & - & - & - \\
\hline 1872 & 31.8 & - & - & - & - & - \\
\hline 1873 & 30.7 & 0.07 & - & - & - & - \\
\hline 1874 & 25.8 & 0.10 & - & - & - & - \\
\hline 1875 & 31.0 & 0.06 & - & - & - & - \\
\hline 1876 & 33.5 & 0.07 & - & - & - & - \\
\hline 1877 & 31.4 & 0.09 & - & - & - & - \\
\hline 1878 & 33.0 & 0.07 & - & - & - & - \\
\hline 1879 & 29.8 & 0.07 & - & - & - & - \\
\hline 1880 & 31.6 & 0.11 & - & - & - & - \\
\hline 1881 & 32.0 & 0.15 & - & - & - & - \\
\hline 1882 & 28.0 & 0.17 & - & - & - & - \\
\hline 1883 & 27.7 & 0.19 & - & - & - & - \\
\hline 1884 & 28.6 & 0.38 & - & - & - & - \\
\hline 1885 & 30.0 & 0.55 & - & - & - & - \\
\hline 1886 & 31.4 & 0.48 & - & - & - & - \\
\hline 1887 & 25.1 & 0.58 & - & - & - & - \\
\hline 1888 & 28.4 & 0.75 & - & - & - & - \\
\hline 1889 & 26.0 & 0.83 & - & - & - & - \\
\hline 1890 & 28.3 & 1.24 & - & - & - & - \\
\hline 1891 & 27.9 & 2.47 & - & - & - & - \\
\hline 1892 & 28.5 & 3.00 & - & - & - & - \\
\hline 1893 & 29.1 & 3.46 & - & - & - & - \\
\hline 1894 & 27.5 & 5.48 & - & - & - & - \\
\hline 1895 & 26.3 & 7.85 & - & - & - & - \\
\hline 1896 & 27.8 & 8.34 & - & - & - & - \\
\hline 1897 & 27.8 & 11.1 & - & - & - & - \\
\hline 1898 & 28.1 & 5.96 & - & - & - & - \\
\hline 1899 & 26.5 & 6.30 & - & - & - & - \\
\hline 1900 & 27.8 & 8.44 & - & - & - & - \\
\hline 1901 & 30.0 & 11.7 & - & - & - & - \\
\hline 1902 & 25.7 & 6.87 & - & - & - & - \\
\hline 1903 & 23.6 & 7.81 & - & - & - & - \\
\hline 1904 & 29.0 & 5.82 & - & - & - & - \\
\hline 1905 & 27.5 & 8.03 & - & - & - & - \\
\hline 1906 & 30.7 & 1.15 & - & - & - & - \\
\hline 1907 & 27.0 & 9.44 & - & - & - & - \\
\hline 1908 & 28.1 & 11.7 & - & - & - & - \\
\hline 1909 & 24.1 & 9.97 & - & - & - & - \\
\hline 1910 & 26.4 & 10.2 & - & - & - & - \\
\hline
\end{tabular}




\begin{tabular}{|c|c|c|c|c|c|c|}
\hline Year & $\begin{array}{l}\text { Alcohol \& } \\
\text { beverages }\end{array}$ & Sugar & Tobacco & Vehicles & $\begin{array}{c}\text { Energy and } \\
\text { environment }\end{array}$ & Other \\
\hline 1911 & 26.3 & 10.4 & - & - & - & - \\
\hline 1912 & 25.9 & 10.4 & - & - & - & - \\
\hline 1913 & 22.9 & 10.6 & - & - & - & - \\
\hline 1914 & 24.4 & 11.4 & - & - & - & - \\
\hline 1915 & 16.7 & 8.54 & 0.94 & - & - & - \\
\hline 1916 & 13.7 & 6.34 & 4.78 & - & - & - \\
\hline 1917 & 4.73 & 2.04 & 3.60 & - & - & - \\
\hline 1918 & 2.30 & 1.55 & 3.89 & - & - & - \\
\hline 1919 & 5.75 & 2.12 & 5.25 & - & - & - \\
\hline 1920 & 9.33 & 3.44 & 5.88 & - & - & - \\
\hline 1921 & 15.8 & 3.94 & 6.54 & - & - & - \\
\hline 1922 & 19.7 & 4.65 & 8.11 & - & - & - \\
\hline 1923 & 16.6 & 5.63 & 8.58 & 1.81 & - & - \\
\hline 1924 & 17.4 & 5.64 & 9.68 & 3.57 & - & - \\
\hline 1925 & 17.7 & 4.97 & 10.1 & 4.26 & - & - \\
\hline 1926 & 18.4 & 3.20 & 10.7 & 4.52 & - & - \\
\hline 1927 & 17.1 & 3.15 & 10.8 & 5.68 & - & - \\
\hline 1928 & 16.6 & 1.45 & 10.9 & 6.95 & - & - \\
\hline 1929 & 18.7 & 0.24 & 11.8 & 7.51 & - & - \\
\hline 1930 & 17.9 & - & 11.0 & 8.60 & - & - \\
\hline 1931 & 19.1 & - & 11.8 & 9.88 & - & - \\
\hline 1932 & 23.1 & - & 12.1 & 12.1 & - & 0.07 \\
\hline 1933 & 23.3 & - & 12.1 & 12.8 & - & 2.02 \\
\hline 1934 & 22.1 & - & 11.4 & 12.7 & - & 2.29 \\
\hline 1935 & 21.9 & - & 11.0 & 12.7 & - & 2.26 \\
\hline 1936 & 20.0 & - & 10.4 & 12.5 & - & 1.90 \\
\hline 1937 & 19.8 & - & 10.3 & 12.4 & - & 2.63 \\
\hline 1938 & 17.9 & - & 9.36 & 11.8 & - & 2.65 \\
\hline 1939 & 18.8 & 0.47 & 9.41 & 10.1 & - & 2.86 \\
\hline 1940 & 17.6 & 1.32 & 10.4 & 3.66 & - & 2.99 \\
\hline 1941 & 15.7 & - & 11.0 & 2.05 & - & 4.10 \\
\hline 1942 & 17.4 & - & 11.0 & 2.61 & - & 4.34 \\
\hline 1943 & 18.1 & - & 10.6 & 3.09 & - & 3.92 \\
\hline 1944 & 17.1 & - & 10.8 & 2.57 & - & 4.15 \\
\hline 1945 & 16.6 & - & 10.8 & 4.21 & - & 3.78 \\
\hline 1946 & 18.2 & - & 11.7 & 7.64 & - & 4.01 \\
\hline 1947 & 15.8 & - & 10.2 & 7.55 & - & 5.26 \\
\hline 1948 & 16.8 & - & 10.5 & 2.83 & 8.32 & 6.68 \\
\hline 1949 & 16.7 & - & 10.3 & 3.09 & 8.55 & 6.12 \\
\hline 1950 & 14.6 & - & 9.28 & 2.83 & 7.22 & 4.18 \\
\hline 1951 & 12.5 & - & 7.70 & 3.39 & 4.39 & 4.48 \\
\hline 1952 & 12.6 & - & 8.63 & 2.77 & 4.83 & 5.42 \\
\hline 1953 & 12.2 & - & 8.32 & 2.87 & 5.24 & 4.78 \\
\hline 1954 & 12.6 & - & 8.10 & 4.14 & 6.19 & 4.35 \\
\hline 1955 & 13.3 & - & 7.37 & 4.93 & 6.56 & 4.14 \\
\hline 1956 & 13.8 & - & 6.84 & 4.65 & 6.49 & 3.98 \\
\hline 1957 & 12.6 & - & 6.87 & 4.45 & 9.15 & 3.35 \\
\hline 1958 & 12.4 & - & 7.37 & 4.36 & 10.5 & 3.45 \\
\hline 1959 & 11.9 & - & 7.18 & 4.52 & 10.8 & 3.21 \\
\hline 1960 & 9.76 & - & 5.98 & 3.99 & 9.21 & 2.78 \\
\hline
\end{tabular}




\begin{tabular}{|c|c|c|c|c|c|c|}
\hline Year & $\begin{array}{l}\text { Alcohol \& } \\
\text { beverages }\end{array}$ & Sugar & Tobacco & Vehicles & $\begin{array}{c}\text { Energy and } \\
\text { environment }\end{array}$ & Other \\
\hline 1961 & 9.53 & - & 5.88 & 3.98 & 8.09 & 2.73 \\
\hline 1962 & 8.36 & - & 5.43 & 3.88 & 9.66 & 2.46 \\
\hline 1963 & 9.76 & - & 5.21 & 4.56 & 9.92 & 2.22 \\
\hline 1964 & 8.68 & - & 4.97 & 4.32 & 9.22 & 1.91 \\
\hline 1965 & 8.10 & - & 4.73 & 4.02 & 9.10 & 1.37 \\
\hline 1966 & 8.30 & - & 4.88 & 4.50 & 8.91 & 1.33 \\
\hline 1967 & 8.23 & - & 5.11 & 4.75 & 8.72 & 1.32 \\
\hline 1968 & 8.00 & - & 4.82 & 5.10 & 8.56 & 1.25 \\
\hline 1969 & 7.56 & - & 4.52 & 5.17 & 8.11 & 1.11 \\
\hline 1970 & 7.18 & - & 4.09 & 5.10 & 7.43 & 0.96 \\
\hline 1971 & 6.76 & - & 3.58 & 5.43 & 6.82 & 0.90 \\
\hline 1972 & 6.84 & - & 3.57 & 5.63 & 6.67 & 0.83 \\
\hline 1973 & 6.32 & - & 3.53 & 5.43 & 6.06 & 1.13 \\
\hline 1974 & 6.39 & - & 3.24 & 4.20 & 5.81 & 1.23 \\
\hline 1975 & 5.61 & - & 2.61 & 3.40 & 5.96 & 1.00 \\
\hline 1976 & 5.44 & - & 2.50 & 3.69 & 5.93 & 1.00 \\
\hline 1977 & 5.09 & - & 2.48 & 3.39 & 6.18 & 0.90 \\
\hline 1978 & 5.51 & - & 2.46 & 3.64 & 7.11 & 0.81 \\
\hline 1979 & 5.41 & - & 2.46 & 3.53 & 7.12 & 0.80 \\
\hline 1980 & 4.79 & - & 2.22 & 2.80 & 7.88 & 1.36 \\
\hline 1981 & 4.84 & - & 2.20 & 2.78 & 8.68 & 1.41 \\
\hline 1982 & 4.55 & - & 1.89 & 2.50 & 9.37 & 2.53 \\
\hline 1983 & 4.78 & - & 2.16 & 2.15 & 8.50 & 2.16 \\
\hline 1984 & 3.77 & - & 1.76 & 2.13 & 8.98 & 2.56 \\
\hline 1985 & 3.77 & - & 1.69 & 2.22 & 10.1 & 2.79 \\
\hline 1986 & 3.50 & - & 1.48 & 1.94 & 8.79 & 2.57 \\
\hline 1987 & 3.42 & - & 1.55 & 1.96 & 9.22 & 2.63 \\
\hline 1988 & 3.27 & - & 1.50 & 1.88 & 9.09 & 2.44 \\
\hline 1989 & 3.25 & - & 1.53 & 1.95 & 9.22 & 2.36 \\
\hline 1990 & 3.56 & - & 1.68 & 2.15 & 9.55 & 2.16 \\
\hline 1991 & 3.57 & - & 1.71 & 2.12 & 9.93 & 1.94 \\
\hline 1992 & 3.59 & - & 1.91 & 2.09 & 10.7 & 1.53 \\
\hline 1993 & 3.69 & - & 2.26 & 1.64 & 12.3 & 1.35 \\
\hline 1994 & 3.35 & - & 2.11 & 1.68 & 11.5 & 0.70 \\
\hline 1995 & 2.74 & - & 1.72 & 1.38 & 9.64 & 0.52 \\
\hline 1996 & 2.10 & - & 1.29 & 1.25 & 8.50 & 0.50 \\
\hline 1997 & 1.71 & - & 1.34 & 1.12 & 8.43 & 0.27 \\
\hline 1998 & 1.56 & - & 1.17 & 1.00 & 8.04 & 0.22 \\
\hline 1999 & 1.58 & - & 1.10 & 0.99 & 7.75 & 0.19 \\
\hline 2000 & 1.62 & - & 1.16 & 1.06 & 7.73 & 0.21 \\
\hline 2001 & 1.61 & - & 1.17 & 1.12 & 8.06 & 0.16 \\
\hline 2002 & 1.68 & - & 1.27 & 1.24 & 9.04 & 0.15 \\
\hline 2003 & 1.80 & - & 1.35 & 1.37 & 10.1 & 0.16 \\
\hline 2004 & 1.61 & - & 1.28 & 1.38 & 9.98 & 0.17 \\
\hline 2005 & 1.48 & - & 1.18 & 1.62 & 10.6 & 0.18 \\
\hline 2006 & 1.34 & - & 1.08 & 1.47 & 8.42 & 0.29 \\
\hline 2007 & 1.33 & - & 1.18 & 1.58 & 8.20 & 0.28 \\
\hline 2008 & 1.45 & - & 1.26 & 2.04 & 8.82 & 0.23 \\
\hline 2009 & 1.65 & - & 1.44 & 2.23 & 9.53 & 0.26 \\
\hline 2010 & 1.54 & - & 1.34 & 2.08 & 9.25 & 0.25 \\
\hline
\end{tabular}




\begin{tabular}{ccccccc}
\hline Year & $\begin{array}{c}\text { Alcohol \& } \\
\text { beverages }\end{array}$ & Sugar & Tobacco & Vehicles & $\begin{array}{c}\text { Energy and } \\
\text { environment }\end{array}$ & Other \\
\hline 2011 & 1.54 & - & 1.42 & 1.99 & 8.87 & 0.26 \\
2012 & 1.59 & - & 1.52 & 2.01 & 8.98 & 0.23 \\
2013 & 1.52 & - & 1.39 & 2.06 & 8.64 & 0.20 \\
\hline
\end{tabular}

Note: Due to classification problems, fuel tax is included in "Vehicles" until 1947 and in "Energy and environment” thereafter.

Source: See Figure 1. 
Table A5. Specific consumption taxes, percent of total tax revenue.

\begin{tabular}{|c|c|c|c|c|c|c|}
\hline Year & $\begin{array}{l}\text { Alcohol \& } \\
\text { beverages }\end{array}$ & Sugar & Tobacco & Vehicles & $\begin{array}{c}\text { Energy and } \\
\text { environment }\end{array}$ & Other \\
\hline 1862 & 14.86 & - & - & - & - & - \\
\hline 1863 & 15.61 & - & - & - & - & - \\
\hline 1864 & 15.52 & - & - & - & - & - \\
\hline 1865 & 16.76 & - & - & - & - & - \\
\hline 1866 & 16.36 & - & - & - & - & - \\
\hline 1867 & 14.95 & - & - & - & - & - \\
\hline 1868 & 12.56 & - & - & - & - & - \\
\hline 1869 & 14.70 & - & - & - & - & - \\
\hline 1870 & 16.75 & - & - & - & - & - \\
\hline 1871 & 18.85 & - & - & - & - & - \\
\hline 1872 & 19.74 & - & - & - & - & - \\
\hline 1873 & 18.71 & 0.04 & - & - & - & - \\
\hline 1874 & 16.43 & 0.06 & - & - & - & - \\
\hline 1875 & 18.83 & 0.04 & - & - & - & - \\
\hline 1876 & 21.21 & 0.04 & - & - & - & - \\
\hline 1877 & 19.38 & 0.06 & - & - & - & - \\
\hline 1878 & 19.73 & 0.04 & - & - & - & - \\
\hline 1879 & 18.13 & 0.04 & - & - & - & - \\
\hline 1880 & 19.89 & 0.07 & - & - & - & - \\
\hline 1881 & 20.37 & 0.09 & - & - & - & - \\
\hline 1882 & 17.45 & 0.11 & - & - & - & - \\
\hline 1883 & 17.34 & 0.12 & - & - & - & - \\
\hline 1884 & 17.87 & 0.24 & - & - & - & - \\
\hline 1885 & 18.75 & 0.35 & - & - & - & - \\
\hline 1886 & 19.32 & 0.30 & - & - & - & - \\
\hline 1887 & 14.15 & 0.33 & - & - & - & - \\
\hline 1888 & 18.07 & 0.48 & - & - & - & - \\
\hline 1889 & 16.87 & 0.54 & - & - & - & - \\
\hline 1890 & 18.63 & 0.81 & - & - & - & - \\
\hline 1891 & 17.54 & 1.55 & - & - & - & - \\
\hline 1892 & 17.90 & 1.88 & - & - & - & - \\
\hline 1893 & 18.42 & 2.19 & - & - & - & - \\
\hline 1894 & 17.84 & 3.56 & - & - & - & - \\
\hline 1895 & 17.33 & 5.18 & - & - & - & - \\
\hline 1896 & 18.56 & 5.56 & - & - & - & - \\
\hline 1897 & 18.59 & 7.45 & - & - & - & - \\
\hline 1898 & 19.27 & 4.08 & - & - & - & - \\
\hline 1899 & 18.59 & 4.42 & - & - & - & - \\
\hline 1900 & 18.86 & 5.72 & - & - & - & - \\
\hline 1901 & 19.43 & 7.55 & - & - & - & - \\
\hline 1902 & 16.62 & 4.44 & - & - & - & - \\
\hline 1903 & 16.01 & 5.30 & - & - & - & - \\
\hline 1904 & 19.33 & 3.88 & - & - & - & - \\
\hline 1905 & 18.24 & 5.33 & - & - & - & - \\
\hline 1906 & 19.69 & 0.74 & - & - & - & - \\
\hline 1907 & 17.52 & 6.13 & - & - & - & - \\
\hline 1908 & 17.53 & 7.33 & - & - & - & - \\
\hline 1909 & 14.29 & 5.90 & - & - & - & - \\
\hline 1910 & 16.12 & 6.25 & - & - & - & - \\
\hline
\end{tabular}




\begin{tabular}{|c|c|c|c|c|c|c|}
\hline Year & $\begin{array}{l}\text { Alcohol \& } \\
\text { beverages }\end{array}$ & Sugar & Tobacco & Vehicles & $\begin{array}{c}\text { Energy and } \\
\text { environment }\end{array}$ & Other \\
\hline 1911 & 16.36 & 6.44 & - & - & - & - \\
\hline 1912 & 15.95 & 6.41 & - & - & - & - \\
\hline 1913 & 14.13 & 6.55 & - & - & - & - \\
\hline 1914 & 14.39 & 6.69 & - & - & - & - \\
\hline 1915 & 11.09 & 5.66 & 0.63 & - & - & - \\
\hline 1916 & 9.25 & 4.29 & 3.23 & - & - & - \\
\hline 1917 & 3.52 & 1.52 & 2.68 & - & - & - \\
\hline 1918 & 1.67 & 1.13 & 2.82 & - & - & - \\
\hline 1919 & 3.98 & 1.47 & 3.63 & - & - & - \\
\hline 1920 & 5.86 & 2.16 & 3.70 & - & - & - \\
\hline 1921 & 8.75 & 2.18 & 3.62 & - & - & - \\
\hline 1922 & 10.5 & 2.47 & 4.31 & - & - & - \\
\hline 1923 & 9.7 & 3.28 & 5.01 & 1.06 & - & - \\
\hline 1924 & 10.8 & 3.50 & 6.01 & 2.22 & - & - \\
\hline 1925 & 10.9 & 3.05 & 6.18 & 2.61 & - & - \\
\hline 1926 & 11.3 & 1.95 & 6.53 & 2.76 & - & - \\
\hline 1927 & 10.5 & 1.93 & 6.62 & 3.47 & - & - \\
\hline 1928 & 10.1 & 0.88 & 6.62 & 4.22 & - & - \\
\hline 1929 & 11.2 & 0.14 & 7.11 & 4.51 & - & - \\
\hline 1930 & 10.8 & - & 6.65 & 5.20 & - & - \\
\hline 1931 & 11.4 & - & 7.03 & 5.89 & - & - \\
\hline 1932 & 14.0 & - & 7.34 & 7.34 & - & 0.04 \\
\hline 1933 & 13.7 & - & 7.13 & 7.48 & - & 1.19 \\
\hline 1934 & 13.6 & - & 7.00 & 7.80 & - & 1.41 \\
\hline 1935 & 14.2 & - & 7.13 & 8.22 & - & 1.46 \\
\hline 1936 & 13.3 & - & 6.92 & 8.33 & - & 1.26 \\
\hline 1937 & 13.2 & - & 6.90 & 8.32 & - & 1.76 \\
\hline 1938 & 12.2 & - & 6.39 & 8.05 & - & 1.81 \\
\hline 1939 & 13.2 & 0.33 & 6.63 & 7.10 & - & 2.02 \\
\hline 1940 & 12.8 & 0.96 & 7.58 & 2.67 & - & 2.17 \\
\hline 1941 & 11.3 & - & 7.90 & 1.48 & - & 2.96 \\
\hline 1942 & 12.7 & - & 8.08 & 1.91 & - & 3.18 \\
\hline 1943 & 13.5 & - & 7.90 & 2.30 & - & 2.92 \\
\hline 1944 & 12.7 & - & 7.99 & 1.91 & - & 3.07 \\
\hline 1945 & 12.4 & - & 8.05 & 3.15 & - & 2.83 \\
\hline 1946 & 13.5 & - & 8.71 & 5.68 & - & 2.98 \\
\hline 1947 & 12.0 & - & 7.75 & 5.74 & - & 4.00 \\
\hline 1948 & 12.4 & - & 7.73 & 2.09 & 6.15 & 4.94 \\
\hline 1949 & 11.1 & - & 6.89 & 2.06 & 5.71 & 4.09 \\
\hline 1950 & 10.9 & - & 6.97 & 2.12 & 5.42 & 3.14 \\
\hline 1951 & 9.83 & - & 6.08 & 2.67 & 3.47 & 3.54 \\
\hline 1952 & 8.21 & - & 5.63 & 1.81 & 3.15 & 3.53 \\
\hline 1953 & 8.43 & - & 5.73 & 1.98 & 3.61 & 3.30 \\
\hline 1954 & 8.68 & - & 5.56 & 2.84 & 4.25 & 2.99 \\
\hline 1955 & 9.51 & - & 5.28 & 3.53 & 4.70 & 2.97 \\
\hline 1956 & 9.16 & - & 4.54 & 3.09 & 4.31 & 2.64 \\
\hline 1957 & 8.62 & - & 4.69 & 3.04 & 6.24 & 2.28 \\
\hline 1958 & 8.35 & - & 4.96 & 2.94 & 7.07 & 2.32 \\
\hline 1959 & 8.20 & - & 4.97 & 3.12 & 7.45 & 2.22 \\
\hline 1960 & 7.12 & - & 4.37 & 2.91 & 6.72 & 2.03 \\
\hline
\end{tabular}




\begin{tabular}{|c|c|c|c|c|c|c|}
\hline Year & $\begin{array}{l}\text { Alcohol \& } \\
\text { beverages }\end{array}$ & Sugar & Tobacco & Vehicles & $\begin{array}{c}\text { Energy and } \\
\text { environment }\end{array}$ & Other \\
\hline 1961 & 6.60 & - & 4.08 & 2.76 & 5.61 & 1.89 \\
\hline 1962 & 5.63 & - & 3.66 & 2.61 & 6.50 & 1.66 \\
\hline 1963 & 6.25 & - & 3.33 & 2.92 & 6.35 & 1.42 \\
\hline 1964 & 5.66 & - & 3.24 & 2.82 & 6.02 & 1.25 \\
\hline 1965 & 5.20 & - & 3.04 & 2.58 & 5.84 & 0.88 \\
\hline 1966 & 5.10 & - & 3.00 & 2.76 & 5.48 & 0.82 \\
\hline 1967 & 4.79 & - & 2.97 & 2.77 & 5.07 & 0.77 \\
\hline 1968 & 4.56 & - & 2.74 & 2.91 & 4.87 & 0.71 \\
\hline 1969 & 4.40 & - & 2.63 & 3.01 & 4.73 & 0.64 \\
\hline 1970 & 4.24 & - & 2.41 & 3.01 & 4.39 & 0.57 \\
\hline 1971 & 3.94 & - & 2.09 & 3.17 & 3.98 & 0.52 \\
\hline 1972 & 3.73 & - & 1.94 & 3.06 & 3.63 & 0.45 \\
\hline 1973 & 3.60 & - & 2.01 & 3.10 & 3.46 & 0.65 \\
\hline 1974 & 3.68 & - & 1.87 & 2.42 & 3.35 & 0.71 \\
\hline 1975 & 3.47 & - & 1.61 & 2.10 & 3.69 & 0.62 \\
\hline 1976 & 3.09 & - & 1.42 & 2.10 & 3.37 & 0.57 \\
\hline 1977 & 2.69 & - & 1.31 & 1.80 & 3.27 & 0.48 \\
\hline 1978 & 2.74 & - & 1.22 & 1.81 & 3.53 & 0.40 \\
\hline 1979 & 2.72 & - & 1.23 & 1.77 & 3.57 & 0.40 \\
\hline 1980 & 2.49 & - & 1.16 & 1.45 & 4.10 & 0.71 \\
\hline 1981 & 2.33 & - & 1.06 & 1.34 & 4.18 & 0.68 \\
\hline 1982 & 2.32 & - & 0.96 & 1.28 & 4.79 & 1.29 \\
\hline 1983 & 2.53 & - & 1.14 & 1.14 & 4.49 & 1.14 \\
\hline 1984 & 2.12 & - & 0.99 & 1.20 & 5.05 & 1.44 \\
\hline 1985 & 2.03 & - & 0.91 & 1.20 & 5.45 & 1.50 \\
\hline 1986 & 1.93 & - & 0.81 & 1.07 & 4.84 & 1.42 \\
\hline 1987 & 1.77 & - & 0.80 & 1.02 & 4.77 & 1.36 \\
\hline 1988 & 1.73 & - & 0.80 & 1.00 & 4.82 & 1.30 \\
\hline 1989 & 1.68 & - & 0.79 & 1.01 & 4.78 & 1.22 \\
\hline 1990 & 1.58 & - & 0.74 & 0.95 & 4.23 & 0.96 \\
\hline 1991 & 1.54 & - & 0.74 & 0.91 & 4.28 & 0.84 \\
\hline 1992 & 1.57 & - & 0.84 & 0.91 & 4.66 & 0.67 \\
\hline 1993 & 1.61 & - & 0.98 & 0.72 & 5.34 & 0.59 \\
\hline 1994 & 1.49 & - & 0.94 & 0.75 & 5.09 & 0.31 \\
\hline 1995 & 1.34 & - & 0.84 & 0.68 & 4.72 & 0.25 \\
\hline 1996 & 1.26 & - & 0.77 & 0.75 & 5.10 & 0.30 \\
\hline 1997 & 1.01 & - & 0.79 & 0.66 & 4.97 & 0.16 \\
\hline 1998 & 0.97 & - & 0.73 & 0.62 & 5.00 & 0.14 \\
\hline 1999 & 0.97 & - & 0.68 & 0.61 & 4.77 & 0.12 \\
\hline 2000 & 0.93 & - & 0.67 & 0.61 & 4.46 & 0.12 \\
\hline 2001 & 0.95 & - & 0.69 & 0.66 & 4.76 & 0.10 \\
\hline 2002 & 0.96 & - & 0.72 & 0.71 & 5.14 & 0.08 \\
\hline 2003 & 0.90 & - & 0.68 & 0.68 & 5.04 & 0.08 \\
\hline 2004 & 0.80 & - & 0.64 & 0.69 & 4.97 & 0.08 \\
\hline 2005 & 0.74 & - & 0.60 & 0.81 & 5.35 & 0.09 \\
\hline 2006 & 0.75 & - & 0.61 & 0.83 & 4.73 & 0.16 \\
\hline 2007 & 0.74 & - & 0.66 & 0.88 & 4.57 & 0.16 \\
\hline 2008 & 0.77 & - & 0.67 & 1.08 & 4.67 & 0.12 \\
\hline 2009 & 0.84 & - & 0.73 & 1.13 & 4.85 & 0.13 \\
\hline 2010 & 0.80 & - & 0.70 & 1.08 & 4.81 & 0.13 \\
\hline
\end{tabular}




\begin{tabular}{rcccccc}
\hline Year & $\begin{array}{c}\text { Alcohol \& } \\
\text { beverages }\end{array}$ & Sugar & Tobacco & Vehicles & $\begin{array}{c}\text { Energy and } \\
\text { environment }\end{array}$ & Other \\
\hline 2011 & 0.79 & - & 0.73 & 1.02 & 4.54 & 0.13 \\
2012 & 0.78 & - & 0.75 & 0.99 & 4.42 & 0.11 \\
2013 & 0.76 & - & 0.69 & 1.02 & 4.29 & 0.10 \\
\hline
\end{tabular}

Note: Due to classification problems, fuel tax is included in "Vehicles" until 1947 and in "Energy and environment” thereafter.

Source: See Figure 1. 
Table A6. Specific consumption taxes, percent of GDP.

\begin{tabular}{|c|c|c|c|c|c|c|}
\hline Year & $\begin{array}{l}\text { Alcohol \& } \\
\text { beverages }\end{array}$ & Sugar & Tobacco & Vehicles & $\begin{array}{c}\text { Energy and } \\
\text { environment }\end{array}$ & Other \\
\hline 1862 & 1.06 & - & - & - & - & - \\
\hline 1863 & 1.12 & - & - & - & - & - \\
\hline 1864 & 1.11 & - & - & - & - & - \\
\hline 1865 & 1.25 & - & - & - & - & - \\
\hline 1866 & 1.15 & - & - & - & - & - \\
\hline 1867 & 0.94 & - & - & - & - & - \\
\hline 1868 & 0.87 & - & - & - & - & - \\
\hline 1869 & 0.96 & - & - & - & - & - \\
\hline 1870 & 1.17 & - & - & - & - & - \\
\hline 1871 & 1.43 & - & - & - & - & - \\
\hline 1872 & 1.36 & - & - & - & - & - \\
\hline 1873 & 1.29 & - & - & - & - & - \\
\hline 1874 & 1.18 & - & - & - & - & - \\
\hline 1875 & 1.29 & - & - & - & - & - \\
\hline 1876 & 1.44 & - & - & - & - & - \\
\hline 1877 & 1.32 & - & - & - & - & - \\
\hline 1878 & 1.42 & - & - & - & - & - \\
\hline 1879 & 1.37 & - & - & - & - & - \\
\hline 1880 & 1.55 & 0.01 & - & - & - & - \\
\hline 1881 & 1.60 & 0.01 & - & - & - & - \\
\hline 1882 & 1.35 & 0.01 & - & - & - & - \\
\hline 1883 & 1.30 & 0.01 & - & - & - & - \\
\hline 1884 & 1.39 & 0.02 & - & - & - & - \\
\hline 1885 & 1.48 & 0.03 & - & - & - & - \\
\hline 1886 & 1.60 & 0.02 & - & - & - & - \\
\hline 1887 & 1.16 & 0.03 & - & - & - & - \\
\hline 1888 & 1.53 & 0.04 & - & - & - & - \\
\hline 1889 & 1.40 & 0.04 & - & - & - & - \\
\hline 1890 & 1.54 & 0.07 & - & - & - & - \\
\hline 1891 & 1.34 & 0.12 & - & - & - & - \\
\hline 1892 & 1.36 & 0.14 & - & - & - & - \\
\hline 1893 & 1.46 & 0.17 & - & - & - & - \\
\hline 1894 & 1.51 & 0.30 & - & - & - & - \\
\hline 1895 & 1.45 & 0.43 & - & - & - & - \\
\hline 1896 & 1.50 & 0.45 & - & - & - & - \\
\hline 1897 & 1.47 & 0.59 & - & - & - & - \\
\hline 1898 & 1.47 & 0.31 & - & - & - & - \\
\hline 1899 & 1.43 & 0.34 & - & - & - & - \\
\hline 1900 & 1.46 & 0.44 & - & - & - & - \\
\hline 1901 & 1.47 & 0.57 & - & - & - & - \\
\hline 1902 & 1.31 & 0.35 & - & - & - & - \\
\hline 1903 & 1.33 & 0.44 & - & - & - & - \\
\hline 1904 & 1.62 & 0.33 & - & - & - & - \\
\hline 1905 & 1.56 & 0.46 & - & - & - & - \\
\hline 1906 & 1.52 & 0.06 & - & - & - & - \\
\hline 1907 & 1.36 & 0.48 & - & - & - & - \\
\hline 1908 & 1.48 & 0.62 & - & - & - & - \\
\hline 1909 & 1.19 & 0.49 & - & - & - & - \\
\hline 1910 & 1.37 & 0.53 & - & - & - & - \\
\hline
\end{tabular}




\begin{tabular}{|c|c|c|c|c|c|c|}
\hline Year & $\begin{array}{l}\text { Alcohol \& } \\
\text { beverages }\end{array}$ & Sugar & Tobacco & Vehicles & $\begin{array}{c}\text { Energy and } \\
\text { environment }\end{array}$ & Other \\
\hline 1911 & 1.42 & 0.56 & - & - & - & - \\
\hline 1912 & 1.37 & 0.55 & - & - & - & - \\
\hline 1913 & 1.15 & 0.53 & - & - & - & - \\
\hline 1914 & 1.18 & 0.55 & - & - & - & - \\
\hline 1915 & 1.03 & 0.53 & 0.06 & - & - & - \\
\hline 1916 & 0.77 & 0.36 & 0.27 & - & - & - \\
\hline 1917 & 0.37 & 0.16 & 0.28 & - & - & - \\
\hline 1918 & 0.19 & 0.13 & 0.32 & - & - & - \\
\hline 1919 & 0.43 & 0.16 & 0.40 & - & - & - \\
\hline 1920 & 0.59 & 0.22 & 0.37 & - & - & - \\
\hline 1921 & 1.07 & 0.27 & 0.44 & - & - & - \\
\hline 1922 & 1.28 & 0.30 & 0.53 & - & - & - \\
\hline 1923 & 1.07 & 0.36 & 0.55 & 0.12 & - & - \\
\hline 1924 & 1.14 & 0.37 & 0.63 & 0.23 & - & - \\
\hline 1925 & 1.11 & 0.31 & 0.63 & 0.27 & - & - \\
\hline 1926 & 1.19 & 0.21 & 0.69 & 0.29 & - & - \\
\hline 1927 & 1.13 & 0.21 & 0.72 & 0.38 & - & - \\
\hline 1928 & 1.09 & 0.09 & 0.71 & 0.45 & - & - \\
\hline 1929 & 1.19 & 0.02 & 0.76 & 0.48 & - & - \\
\hline 1930 & 1.15 & - & 0.71 & 0.55 & - & - \\
\hline 1931 & 1.31 & - & 0.80 & 0.67 & - & - \\
\hline 1932 & 1.71 & - & 0.89 & 0.89 & - & 0.01 \\
\hline 1933 & 1.72 & - & 0.90 & 0.94 & - & 0.15 \\
\hline 1934 & 1.69 & - & 0.87 & 0.97 & - & 0.18 \\
\hline 1935 & 1.72 & - & 0.86 & 1.00 & - & 0.18 \\
\hline 1936 & 1.65 & - & 0.86 & 1.03 & - & 0.16 \\
\hline 1937 & 1.64 & - & 0.86 & 1.03 & - & 0.22 \\
\hline 1938 & 1.66 & - & 0.87 & 1.09 & - & 0.24 \\
\hline 1939 & 1.96 & 0.05 & 0.98 & 1.05 & - & 0.30 \\
\hline 1940 & 2.01 & 0.15 & 1.19 & 0.42 & - & 0.34 \\
\hline 1941 & 1.80 & - & 1.26 & 0.23 & - & 0.47 \\
\hline 1942 & 2.18 & - & 1.38 & 0.33 & - & 0.54 \\
\hline 1943 & 2.42 & - & 1.41 & 0.41 & - & 0.52 \\
\hline 1944 & 2.35 & - & 1.48 & 0.35 & - & 0.57 \\
\hline 1945 & 2.42 & - & 1.57 & 0.62 & - & 0.55 \\
\hline 1946 & 2.39 & - & 1.54 & 1.00 & - & 0.53 \\
\hline 1947 & 2.42 & - & 1.56 & 1.15 & - & 0.80 \\
\hline 1948 & 2.57 & - & 1.60 & 0.43 & 1.27 & 1.02 \\
\hline 1949 & 2.38 & - & 1.47 & 0.44 & 1.22 & 0.87 \\
\hline 1950 & 2.15 & - & 1.37 & 0.42 & 1.06 & 0.62 \\
\hline 1951 & 1.97 & - & 1.22 & 0.54 & 0.69 & 0.71 \\
\hline 1952 & 1.88 & - & 1.29 & 0.41 & 0.72 & 0.81 \\
\hline 1953 & 1.92 & - & 1.30 & 0.45 & 0.82 & 0.75 \\
\hline 1954 & 2.00 & - & 1.28 & 0.65 & 0.98 & 0.69 \\
\hline 1955 & 2.23 & - & 1.24 & 0.83 & 1.10 & 0.70 \\
\hline 1956 & 2.28 & - & 1.13 & 0.77 & 1.07 & 0.66 \\
\hline 1957 & 2.18 & - & 1.19 & 0.77 & 1.58 & 0.58 \\
\hline 1958 & 2.14 & - & 1.27 & 0.75 & 1.81 & 0.60 \\
\hline 1959 & 2.06 & - & 1.25 & 0.79 & 1.88 & 0.56 \\
\hline 1960 & 1.93 & - & 1.18 & 0.79 & 1.82 & 0.55 \\
\hline
\end{tabular}




\begin{tabular}{|c|c|c|c|c|c|c|}
\hline Year & $\begin{array}{l}\text { Alcohol \& } \\
\text { beverages }\end{array}$ & Sugar & Tobacco & Vehicles & $\begin{array}{c}\text { Energy and } \\
\text { environment }\end{array}$ & Other \\
\hline 1961 & 1.87 & - & 1.16 & 0.78 & 1.59 & 0.54 \\
\hline 1962 & 1.68 & - & 1.09 & 0.78 & 1.94 & 0.49 \\
\hline 1963 & 1.91 & - & 1.02 & 0.89 & 1.94 & 0.43 \\
\hline 1964 & 1.75 & - & 1.00 & 0.87 & 1.86 & 0.39 \\
\hline 1965 & 1.72 & - & 1.00 & 0.85 & 1.93 & 0.29 \\
\hline 1966 & 1.75 & - & 1.03 & 0.95 & 1.88 & 0.28 \\
\hline 1967 & 1.69 & - & 1.05 & 0.98 & 1.79 & 0.27 \\
\hline 1968 & 1.68 & - & 1.01 & 1.07 & 1.80 & 0.26 \\
\hline 1969 & 1.64 & - & 0.98 & 1.12 & 1.76 & 0.24 \\
\hline 1970 & 1.58 & - & 0.90 & 1.13 & 1.64 & 0.21 \\
\hline 1971 & 1.56 & - & 0.83 & 1.26 & 1.58 & 0.21 \\
\hline 1972 & 1.50 & - & 0.78 & 1.23 & 1.46 & 0.18 \\
\hline 1973 & 1.40 & - & 0.78 & 1.20 & 1.34 & 0.25 \\
\hline 1974 & 1.49 & - & 0.76 & 0.98 & 1.36 & 0.29 \\
\hline 1975 & 1.46 & - & 0.68 & 0.88 & 1.55 & 0.26 \\
\hline 1976 & 1.40 & - & 0.64 & 0.95 & 1.53 & 0.26 \\
\hline 1977 & 1.28 & - & 0.62 & 0.85 & 1.55 & 0.23 \\
\hline 1978 & 1.31 & - & 0.59 & 0.87 & 1.69 & 0.19 \\
\hline 1979 & 1.27 & - & 0.57 & 0.83 & 1.66 & 0.19 \\
\hline 1980 & 1.16 & - & 0.54 & 0.67 & 1.90 & 0.33 \\
\hline 1981 & 1.11 & - & 0.51 & 0.64 & 2.00 & 0.33 \\
\hline 1982 & 1.09 & - & 0.45 & 0.60 & 2.24 & 0.60 \\
\hline 1983 & 1.20 & - & 0.54 & 0.54 & 2.13 & 0.54 \\
\hline 1984 & 1.00 & - & 0.46 & 0.56 & 2.37 & 0.68 \\
\hline 1985 & 0.96 & - & 0.43 & 0.57 & 2.58 & 0.71 \\
\hline 1986 & 0.96 & - & 0.40 & 0.53 & 2.40 & 0.70 \\
\hline 1987 & 0.92 & - & 0.42 & 0.53 & 2.49 & 0.71 \\
\hline 1988 & 0.89 & - & 0.41 & 0.51 & 2.48 & 0.67 \\
\hline 1989 & 0.87 & - & 0.41 & 0.52 & 2.48 & 0.63 \\
\hline 1990 & 0.82 & - & 0.39 & 0.50 & 2.21 & 0.50 \\
\hline 1991 & 0.77 & - & 0.37 & 0.46 & 2.14 & 0.42 \\
\hline 1992 & 0.74 & - & 0.40 & 0.43 & 2.20 & 0.32 \\
\hline 1993 & 0.74 & - & 0.45 & 0.33 & 2.46 & 0.27 \\
\hline 1994 & 0.69 & - & 0.43 & 0.35 & 2.36 & 0.14 \\
\hline 1995 & 0.64 & - & 0.40 & 0.32 & 2.24 & 0.12 \\
\hline 1996 & 0.62 & - & 0.38 & 0.37 & 2.52 & 0.15 \\
\hline 1997 & 0.51 & - & 0.40 & 0.33 & 2.51 & 0.08 \\
\hline 1998 & 0.49 & - & 0.37 & 0.31 & 2.54 & 0.07 \\
\hline 1999 & 0.50 & - & 0.35 & 0.31 & 2.44 & 0.06 \\
\hline 2000 & 0.48 & - & 0.34 & 0.31 & 2.29 & 0.06 \\
\hline 2001 & 0.47 & - & 0.34 & 0.33 & 2.35 & 0.05 \\
\hline 2002 & 0.45 & - & 0.34 & 0.34 & 2.44 & 0.04 \\
\hline 2003 & 0.43 & - & 0.32 & 0.33 & 2.41 & 0.04 \\
\hline 2004 & 0.39 & - & 0.31 & 0.33 & 2.39 & 0.04 \\
\hline 2005 & 0.36 & - & 0.29 & 0.40 & 2.62 & 0.04 \\
\hline 2006 & 0.36 & - & 0.29 & 0.40 & 2.29 & 0.08 \\
\hline 2007 & 0.35 & - & 0.31 & 0.42 & 2.17 & 0.07 \\
\hline 2008 & 0.36 & - & 0.31 & 0.50 & 2.17 & 0.06 \\
\hline 2009 & 0.39 & - & 0.34 & 0.53 & 2.26 & 0.06 \\
\hline 2010 & 0.36 & - & 0.32 & 0.49 & 2.19 & 0.06 \\
\hline
\end{tabular}




\begin{tabular}{rcccccc}
\hline Year & $\begin{array}{c}\text { Alcohol \& } \\
\text { beverages }\end{array}$ & Sugar & Tobacco & Vehicles & $\begin{array}{c}\text { Energy and } \\
\text { environment }\end{array}$ & Other \\
\hline 2011 & 0.35 & - & 0.32 & 0.45 & 2.02 & 0.06 \\
2012 & 0.35 & - & 0.33 & 0.44 & 1.96 & 0.05 \\
2013 & 0.34 & - & 0.31 & 0.45 & 1.90 & 0.04 \\
\hline
\end{tabular}

Note: Due to classification problems, fuel tax is included in "Vehicles" until 1947 and in "Energy and environment” thereafter.

Source: See Figure 2. 


\section{References}

Du Rietz, Gunnar, Dan Johansson, and Mikael Stenkula (2015). “Swedish Labor Income Taxation (1862-2013).” IFN Working Paper nr 977, published as chapter 2, pp. 35-122 in Swedish Taxation: Developments since 1862, edited by Magnus Henrekson and Mikael Stenkula. New York: Palgrave Macmillan.

Edvinsson, Rodney, Tor Jacobson, and Daniel Waldenström (eds.) (2014). House Prices, Stock Returns, National Accounts, and the Riksbank Balance Sheet, 1620-2012. Historical Monetary and Financial Statistics for Sweden. Volume II. Stockholm: Ekerlids and Sveriges Riksbank.

Ekonomistyrningsverket (2010). Tidsserier, Statsbudgeten m.m. 2009. ESV 2010:20. Stockholm: Ekonomistyrningsverket [Swedish National Financial Management Authority].

Ekonomistyrningsverket (2011). Tidsserier, statens budget m.m. 2010. ESV 2011:21. Stockholm: Ekonomistyrningsverket [Swedish National Financial Management Authority].

Ekonomistyrningsverket (2012). Tidsserier, statens budget m.m. 2011. ESV 2012:28. Stockholm: Ekonomistyrningsverket [Swedish National Financial Management Authority].

Ekonomistyrningsverket (2013). Tidsserier, statens budget m.m. 2012. ESV 2013:38.

Stockholm: Ekonomistyrningsverket [Swedish National Financial Management Authority].

Ekonomistyrningsverket (2014). Tidsserier, statens budget m.m. 2013. ESV 2014:41.

Stockholm: Ekonomistyrningsverket [Swedish National Financial Management Authority].

Gårestad, Peter (1987). Industrialisering och beskattning i Sverige 1861-1914. Doctoral

Dissertation. Department of Economic History, Uppsala University.

Rodriguez, Enrique. 1980. Offentlig inkomstexpansion: en analys av drivkrafterna bakom de offentliga inkomsternas utveckling i Sverige under 1900-talet. Lund: Liber Läromedel. SCB (1914-2011). Statistical Yearbook of Sweden. Örebro: Statistiska Centralbyrån. Skatteverket (2011). Hanledning för mervärdesskatt 2012, del 2, SKV 554. Stockholm:

Nordstedts Juridik. 
Skatteverket (2012). Skattestatistisk årsbok 2012. Stockholm: Skatteverket [Swedish Tax Agency].

Skatteverket (2013). Skattestatistisk årsbok 2013. Stockholm: Skatteverket [Swedish Tax Agency].

Slemrod, Joel and Jon Bakija (2008). Taxing Ourselves. Cambridge, MA: MIT Press.

SOU 2005:57. Enhetlig eller differentierad mervärdesskatt? Stockholm: Fritzes.

Steinmo, Sven (1993). Taxation \& Democracy. New Haven, CT, and London: Yale University Press. 